\title{
Spor Yöneticiliği Lisans Programının Deneyimsel Öğrenme Yaklaşımını Kullanma Bakımından Yeterliği: Yaşar Doğu Spor Bilimleri Fakültesi Spor Yöneticiliği Programı Örneği
}

Competence of Sports Management Undergraduate Program in Terms of Using Experiential Learning Approach: The Example of Yasar Dogu Sport Sciences Faculty Sports Management Program*

\author{
Fatih Mehmet Parlar ${ }^{* *}$ - Musa Çon ${ }^{* * *}$
}

\begin{abstract}
The Sports Management Accreditation Commission (COSMA) proposes to implement the curriculum in the Sports Management programs as a whole based on experiential learning approach. Therefore, in this research, Ondokuz Mayıs University Yaşar Doğu Sports Sciences Faculty Sports Management program's is to examine the competence in terms of the use of the experiential learning approach in learningteaching activities. In the study, which was designed as a case study, the data were collected through interview pattern, which is one of the qualitative research methods. In this context, in terms of using the experiential learning approach in order to collect in-depth data on the competence of the program, in 2018-19 Academic Year Spring Semester, focus group interview with 7 people from the fourth grade, and with a program manager and a profession lecturer individual interviews were held. Prior to the study, approval was obtained from the Social and Human Sciences Ethics Committee of Ondokuz Mayıs University (2018/320) regarding the ethical compliance of the study. For the validity and reliability of the study data, the "Reliability ", "Transferability", "Consistency" and "Confirmability" techniques used in qualitative research were used. The obtained data were deciphered with the descriptive analysis technique in MAXQDA program. As a result of the research, determined that the program was insufficient in terms of physical environment. On the other hand, it has been determined that although it provides some competencies in terms of sector cooperation, in classroom and out of classroom learning activities, internship training, guidance services and experiential learning outcomes, it is also found to be insufficient. It is recommended that measures should be taken by the program to provide the learners with opportunities to achieve vocational experiences and skills by doing-living inside and outside the campus.
\end{abstract}

\footnotetext{
* Bu arştırmanın etik açıdan uygunluğuna ilişkin onaylar, Ondokuz Mayıs Üniversitesi Sosyal ve Beşerî Bilimler Etik Kurulu'undan (2018/320) alınmıştır. Bu makale, "Spor Yöneticiliği Programlarında Deneyimsel Öğrenme” adlı Doktora Tezinden türetilmiştir.

*** Doktora Öğrencisi, Ondokuz Mayıs Üniversitesi, Lisansüstü Eğitim Enstitüsü, Spor Yöneticiliği Anabilim Dalı PhD. Student, Ondokuz Mayls University, Institude of Graduate Studies, Department of Sports Management ORCID 0000-0002-3401-4078

fatihmehmetparlar@gmail.com

*** Doç. Dr., Ondokuz Mayıs Üniversitesi, Yaşar Doğu Spor Bilimleri Fakültesi, Spor Yöneticiliği Bölümü. Assoc. Prof. Dr., Ondokuz Mayls University, Yaşar Doğu Faculty of Sport Sciences, Department of Sports Management ORCID 0000-0003-3208-5339

musacon@omu.edu.tr

Cite as/ Atıf: Parlar, F. M. \& Çon, M. (2020). Spor yöneticiliği lisans programının deneyimsel öğrenme yaklaşımını kullanma bakımından yeterliği: Yaşar Doğu Spor Bilimleri Fakültesi Spor Yöneticiliği Programı örneği, Turkish Studies - Education, 15(4), 2917-2941. https://dx.doi.org/10.47423/TurkishStudies.44137

Received/Geliş: 10 June/Haziran 2020

Accepted/Kabul: 27 August/Ağustos 2020

Copyright (C INTAC LTD, Turkey
} 
Structured Abstract: The aim of the Sport Management academic programs existing at the higher education level is to improve the workforce would manage the activities in the sports sector in a rational way, which have knowledge, skills and competencies. Experiential learning is defined as the learning occurs as a result of experiences and it is a learning-teaching approach that must be utilized in higher education programs (Itin, 1999: 91; Cooper et al., 2004: 12; Diconti, 2004: 168; Cantor, 1995: 4-12). The Sports Management Accreditation Commission (COSMA) proposes to implement the curriculum in the Sports Management programs as a whole based on experiential learning approach (Sports Management Accreditation Commission, 2016). On the other hand, which has the authority to accredit Sports Management programs in Turkey "Sport Science Curriculum Assessment and Accreditation Council"'s in the program evaluation principles, "Skill development" is considered as the basic basis (Association of Sports Sciences, 2020). In this context, it is important that Sports Management programs use the experiential learning approach which is prove its functionality in developing professional skills, and provide some competencies in this regard, in order to achieve the planned learning outcomes. There are some studies in the literature on the use of experiential learning approach and its effectiveness in learning in Sport Management programs. In these studies, the experimental learning areas of the Sports Management program were tried to be determined and the effects on the development of the personal characteristics of the students were investigated. However, there is no study on the competency of the programs in terms of experiential learning approach. However, the aim of Sports Management programs is to develop the human resources with practical skills and experience that can supply the expectations of the sector. Therefore, it can be said that Sports Management programs should benefit from experiential learning approach in learning-teaching activities and also have some competencies in this field. In this research, the Sports Management program in "Yasar Dogu Sports Science Faculty" within the body " Ondokuz Mayıs University" in Turkey, is it sufficient in term of use experiential learning approach in teachinglearning activities? aimed to find the answer to the question.

Literature Review and Research Questions: In line with purpose the study, the literature has been reviewed on the use of experiential learning approach in Sport Management programs and research questions have been developed. It is emphasized in many studies that the program should be in cooperation with the sector (Devecioglu, 2005: 3; Coknaz and Bulut, 2013: 56; Ardahan, 2010: 696; Dees and Hall, 2012: 71). Therefore, what is the sufficient of the Program in terms of sector cooperation? The answer to the question was sought (Q1). Out of classroom learning activities are considered to offer experiential learning opportunities in Sports Management programs (Cuneen ve Parks, 1997: 125-131; Judge et al., 2011: 33). Therefore, what is the Program's sufficient for out of classroom learning activities? The answer to the question was sought (Q2). Internship training is a widely used experiential learning area in Sports Management programs (Jowdy et al., 2004: 215). So what is the sufficient of the program in terms of internship education? The answer to the question was sought (Q3). Some learning-teaching techniques (role-play, drama, etc.) that can be applied in the classroom can provide students with professional experiences (Foster and Dollar, 2010; Zakus et al., 2007: 149). In this context, what is the sufficient of the program in terms of classroom learning activities? The answer to the question was sought (Q4). It is known that the physical environment in which academic programs are located is decisive for students to make practice (Lidon et al., 2011: 301; Tonbul, 2003: 98). For this reason, what is the program's sufficient in terms of physical environment? The answer to the question was sought (Q5). In sports management programs, guidance services are given importance for directing students to areas where they can gain experience (Ross and McCullough, 2014: 119). In this respect, what is the sufficient of the program in terms of guidance services? The answer to the question was sought (Q6). Finally, it should be known whether the learning-teaching activities in the program cause the changes expected from the students (Melia, Krishman-Melia, 2020). So what is the sufficient of the Program in terms of experiential learning outcome? The answer to the question was sought (Q7).

Method: This research was designed with a case study pattern and data were collected using interview technique, which is one of the qualitative research methods (Creswell, 2013). The research participants consist of 4th grade students determined by the criterion sampling technique from the Ondokuz May1s University Yaşar Doğu Sports Sciences Faculty Sports Management program, and one program manager and one profession lecturer. In this context, in terms of using the experiential learning approach in order to collect indepth data on the competence of the program, in 2018-19 Academic Year Spring Semester, focus group interview with 7 people from the fourth grade, and with a program manager and a profession lecturer individual interviews were held. The data in the study were obtained through the interview form prepared by the research team. Before creating the questions in the data collection tool, the relevant literature was examined and expert

Turkish Studies - Education, 15(4) 
opinion was consulted. The questions prepared to be open-ended based on semi-structured technique were first tested on an academic and a student who were excluded from the research and then the final form was obtained. The questions asked to the participants were designed to determine the competencies and insufficient of the program in the fields of industry collaboration, in and out of classroom experiential learning activities, guidance services, physical environment, internship training and experiential learning outcome. The obtained data were deciphered with the descriptive analysis technique in MAXQDA V.18 program. Prior to the study, approval was obtained from the Social and Human Sciences Ethics Committee of Ondokuz Mayıs University (2018/320) regarding the ethical compliance of the study.For the validity and reliability of the study data, the "Reliability ", "Transferability", "Consistency" and "Confirmability" techniques used in qualitative research were used (Creswell, 2013; Yıldırım and Şimşek, 2008). "Long-term interaction", "Expert review" and "Participant confirmation" tactics were used for the reliability of the data. In order to ensure that the data can be transferred, "Purposeful sampling" selection was preferred. Miles and Huberman (1994) "Consensus / (Consensus + Disagreement)" technique was used for consistency and a $84 \%$ compliance score was found. For confirmability, the raw data collected in the study were archived by the researchers.

Results: Findings were obtained in the sub-theme "Activity" related to the competence of the program in terms of sector cooperation, and in the sub-themes "Communication", "Human Resources", "Employment" and "Planning" related to the insufficient of the program (Q1). In terms of out of classroom learning activities, findings were obtained in the "Research" and "Activity" sub-themes related to the competence of the program, while findings were obtained in the sub-themes of "Curriculum", "Student profile", "Planning" and "Management support" in terms of insufficient the program's (Q2). The findings related to the competence of the internship training of the program appeared in the sub-themes of "Control" and "Workplace selection", while the findings related to the insufficient of the program were obtained in the sub-themes of "Goal awareness", "Legislation", "Number of students", "Planning" and "Internship workplace" (Q3). In terms of classroom learning activities, findings were obtained in the sub-theme "Active learning" regarding the competence of the program, while findings were reached in the sub-themes "Active learning", "Curriculum" and "Number of students" regarding the insufficient of the program (Q4). While positive opinions were not obtained from the participants regarding the competence of the program in terms of physical environment (S5), findings were obtained in the sub-themes of "Settlement pattern" and "Field of application" regarding the insufficient of the program (Q5). In terms of guidance services, findings were obtained in the sub-theme Consulting", "Dialog", "Orientation" and "Vocational guidance" regarding the competence of the program, while findings were reached in the sub-themes "Consultancy", "Career planning", "Number of students" and "Vocational guidance" regarding the insufficient of the program (Q6). In terms of experiential learning outcomes, findings were obtained in "Employment" and "Gaining experience" sub-themes related to program competence, while findings were obtained in "Curriculum", "Workplace Experience", "Field of application" and "Competence" sub-themes related to program insufficient. (Q7).

Discussion and Conclusion: As a result of the research, determined that the program was insufficient in terms of physical environment. On the other hand, it has been determined that although it provides some competencies in terms of sector cooperation, in classroom and out of classroom learning activities, internship training, physical environment, guidance services and experiential learning outcomes, it is also found to be insufficient. Physical properties of the campus where sports management education programs carry out learning-teaching activities can help to experience the learning process (Lidon, Rebollar and Moller, 2011: 301). It was understood that the program evaluated in this research was insufficient in terms of physical environment. For this reason, it can be recommended to update the campus where the program is located so that students can make professional practices. It was observed that there were program insufficiency in terms of sector cooperation. In the related literature, it is said that Sports Management programs should definitely benefit from the cooperation of the sector (Devecioglu, 2005: 3; Coknaz and Bulut, 2013: 56; Ardahan, 2010: 696; Dees and Hall, 2012: 71; Schneider and Stier, 2006: 39). For this reason, it can be said that the program should carry out studies to improve sector cooperation. Out of classroom learning activities can also contribute to the development of leadership, entrepreneurship, and innovation features of sports manager candidates in their fields of interest and integration into the sector in this process (Jowdy, McDonald and Spence, 2004: 230). On the other hand, when in classroom experiential learning activities are evaluated in terms of Sports Management education, it is considered that it will be beneficial to use it in vocational courses since sports management's is an area that requires application skill (Foster and Dollar, 2010; Zakus et al., 2007: 149). When the findings are examined, determined that the program's in and out of classroom learning activities are 
insufficient. Therefore, taking measures to overcome the program's insufficient in these themes can help the program's achieve its goals. Another remarkable finding in the research is related to internship education. Findings on this theme indicate that internship training is insufficient. The internship training process should be supervised by the program's internship coordination and internship workplace consultants, and the timely and appropriate work given to students in internship training should be under the constant (daily) supervision and guidance of the internship inspector (Schneider and Stier, 2006: 40). Therefore, the competence of the program can be increased by making protocols between the program and internship workplaces. Another finding obtained in the study is on the theme of guidance services. In this theme, although the program has some competencies, it is seen that its insufficient are higher. With effective guidance services, of the students can contribute to reach their career goals and develop their professional skills (Braunstein-Minkove and Deluca, 2015: 20; Hardin et al., 2013: 50). For this reason, it can be beneficial for program outcomes if the program management takes measures against the insufficient in this theme. Finally, when the findings related to the experiential learning outcome of the program were examined, it was seen that there were more findings regarding the insufficient. Studies in the literature show that learning activities based on experiential learning cause positive development and changes in students (Eyler, 2009: 24; Pierson and Troppe, 2010: 12-14; Cunningham et al., 2005: 52; Straughan et al., 2018: 123). For this reason, it can be contributed to the development of the competencies and skills of the learners by applying the experiential practices more effectively in the learning-teaching process of the program. When the findings obtained within the scope of the research questions are evaluated in general, it is seen that the program has insufficiencies in terms of experiential learning approach. For this reason, it is considered that it would be beneficial to take measures regarding the use learning methods based on experiences in program. In addition, in future research, it is recommended to measure the competence of sports management programs in terms of experiential learning approach by quantitative methods.

Keywords: Sports Management, Higher Education, Learning, Experiential Learning, Competence.

Öz: Spor Yöneticiliği Akreditasyon Komisyonu (SYAK), Spor Yöneticiliği programlarındaki müfredatın bütüncül bir şekilde deneyimsel öğrenme yaklaşımına dayalı olarak uygulanmasını önermektedir. Dolayısıyla bu araştırmada, Ondokuz Mayıs Üniversitesi Yaşar Doğu Spor Bilimleri Fakültesi Spor Yöneticiliği programının öğrenme öğretme faaliyetlerinde deneyimsel öğrenme yaklaşımını kullanımı bakımından yeterliğinin değerlendirilmesi amaçlanmıştır. Durum çalışmasıyla kurgulanan araştırmada veriler, nitel araştırma yöntemlerinden görüşme deseni ile toplanmıştır. Araştırma ekibi tarafından geliştirilen veri toplama aracı; 2018/19 Akademik Yılında, Spor Yöneticiliği programının dördüncü sınıf öğrencileri ile odak grup görüşmesi, program yöneticisi ve meslek öğretim elemanı ile de yüz yüze bireysel görüşme yapılarak uygulanmıştır. Araştırma öncesinde Ondokuz Mayıs Üniversitesi Sosyal ve Beşerî Bilimler Etik Kurulu'ndan (2018/320) çalışmanın etik açıdan uygunluğuna ilişkin onay alınmıştır. Çalışma verilerinin geçerlik ve güvenirliğini temin etme için nitel araştırmalarda kullanılan "İnandırıcılık”, "Aktarılabilirlik", "Tutarlık” ve "Teyit edilebilirlik" tekniklerinden yararlanılmıştır. Betimsel analiz yöntemi ile deşifre edilen verilerin çözümlenmesinde MAXQDA nitel veri analizi programı kullanılmıştır. Araştırma neticesinde programın deneyimsel öğrenme yaklaşımını kullanımı bakımından; fiziki çevre temasında yetersiz olduğu; sektör iş birliği, sınıf içi ve dışı öğrenme etkinlikleri, staj eğitimi, rehberlik hizmetleri ve deneyimsel öğrenme çıktısı temalarında bazı yeterlikleri sağlasa da yetersizliklerinin daha fazla olduğu tespit edilmiştir. Programın; öğrenenlere, yerleşke içinde ve dışında yaparak-yaşayarak mesleki deneyim ve beceriler kazandıracak fırsatların sunulmasına yönelik tedbirler alması önerilmektedir.

Anahtar Kelimeler: Spor Yöneticiliği, Yükseköğretim, Öğrenme, Deneyimsel Öğrenme, Yeterlik.

\section{Giriş}

Deneyimsel öğrenme; öğrenmenin, deneyimler sonucu meydana gelmesi şeklinde tanımlanmaktadır (Itin, 1999: 91). Deneyimsel öğrenme yaklaşımı ile ilgili birçok kuram ortaya atılmış olup kökleri pragmatist düşünceye dayanmaktadır. Pragmatist anlayışta kavramların anlamı olaylar, hareketler ya da denemelerde ortaya çıkmakta, onlar için düşünülen ya da tasarlanan şeyin bir anlamı olmadığı, anlamların ancak gerçek hayatta, bireyin etrafı ile olan ilişkilerinde ortaya 
çıkacağı savunulmaktadır (Doğan, 2003: 84). Dewey, öğrenmede deneyimi merkeze alırken Lewin, öğrenmede bireylerin etkin olmasını vurgulamaktadır. Diğer taraftan Piaget ise öğrenme ile ilgili olarak zekanın yalnızca doğuştan var olan özellik olmadığını, birey ve çevre arasında yaşanan etkileşimlerin bir neticesi olduğunu ileri sürmüştür. Kolb'un deneyimsel öğrenme kuramında ise bireyler her zaman aynı şekilde öğrenmemekte ve öğrenme deneyimler sonucunda oluşmaktadır (Kolb, 1984:22-23). Deneyimsel öğrenme kuramında eğitim, temelde öğrenme tarzına uygun eğitim etkinliklerinin planlanmasını zorunlu kılmaktadır. Kolb'a göre bireyler bir konuyu öğrenmede dört aşamadan geçmektedirler. Öğrenme süreci, ilk olarak somut deneyim ile başlayıp yansitıcı gözleme, ardından soyut kavramsallaştırma ile devam edip aktif deneyim ile sonlanmalıdır (Kolb, 1999: 8). Ayrıca Kolb, Dewey'in 1930'lu yıllardaki çalışmasında, yeni eğitim felsefesinin temel bütünlügünün, gerçek deneyim ve eğitim süreçleri arasında samimi ve gerekli bir ilişki olduğu fikrine sahip olduğunu düşünmektedir. Kolb'un deneyimsel öğrenme modelinde; eğitim, iş ve kişisel gelişim arasındaki bağlantıların güçlendirilmesi söz konusudur. Şekil 1'de de görüldüğü üzere bu model iş taleplerini ve karşılık gelen eğitim hedeflerini tanımlamak için bir yeterlikler sistemi sunar ve deneyimsel öğrenme yöntemleriyle sınıf ve "gerçek dünya" arasında geliştirilebilecek kritik bağlantıları vurgular (Kolb, 2015: 4-5).

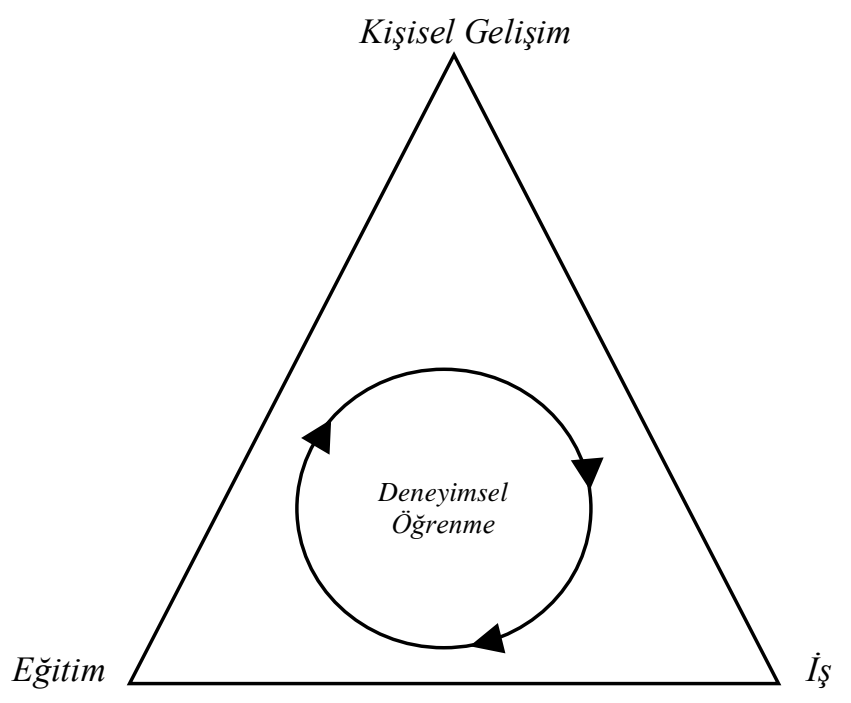

Şekil 1. Eğitim, iş ve kişisel gelişimi bağlayan bir süreç olarak deneyimsel öğrenme

Literatürdeki pekçok çalışma, öğrenme-öğretme faaliyetlerinin sürdürülmesinde deneyimsel öğrenme yöntemlerinden yararlanılmasının yüksek öğretimdeki etkinliği arttırabileceğini göstermektedir. Örneğin Cooper vd., (2004: 12) öğrenenlerin; mesleki becerilerinin geliştirilmesi, istihdam edilebilirliklerinin arttırılması ve iş hayatındaki rekabette önde olabilmeleri için kendilerine avantaj sağlayacak bilgi ve deneyimleri kazanma firsatı istediklerini bildirmiş ve üniversitelerin bilgi ve deneyimi kazandırmadaki rolünün artırılmasına dikkat çekmiştir. Diconti, (2004:168) ise üniversitelerin geleneksel öğretim metotlarının yanında deneyimsel öğrenme tekniklerinden de yararlanması gerektiğini savunmaktadır. Mcglinn (2003: 144) de üniversite yönetimlerinin ve eğitimcilerin deneyimsel öğrenme tekniklerini kullanılmasına yönelik tedbir almasının iş birliğine dayalı keşifsel etkileşimlere imkân tanıyacağını vurgulamaktadır. Cantor (1995:4-12) ise akademik programlarda öğrenme hedeflerine varılabilmesi için öğrenme teorileri ve bilişsel gelişim hakkında artan bir anlayış gösterilmesini, çok sayıda öğrenme stili ve gereksinimi olan öğrenenlerin tanınması ve yükseköğretimin iş dünyası-toplumla daha yakın ilişki içinde olması gerektiğini dile getirmektedir. Yükseköğretim kurumlarında deneyimsel öğrenmeye dair uygulamalar, alana göre değişkenlik gösterse de genel manada; iş birlikçi eğitim, işyerinde eğitim, simülasyonlar, deneyime 
dayalı egzersizler ve iş başında öğrenme, rol modellerle etkileşim, projeye dayalı etkinlikler, aktif öğrenme etkinlikleri, hizmet öğrenme ve tartışma ortamları olarak sıralanabilir (Kolb, 2015: 18; Healey ve Jenkins, 2000: 186; Lewis ve Williams, 1994: 7).

Yükseköğretim düzeyinde eğitim-öğretim programlarından birisi de Spor Bilimleri alanında yer alan Spor Yöneticiliği programlarıdır. Dünya'da ve Türkiye'de Spor Yöneticiliği programları, üniversiteler bünyesinde önlisans, lisans, yüksek lisans ve doktora düzeyinde bulunmakta olup Türkiye'deki Spor Yöneticiliği akademik programları lisans düzeyinde ilk defa 1993 yılında açılmıştır. Yükseköğretim Kurulu verilerine göre 2020 Temmuz ayı itibari ile Türkiye'de aktif Spor Yöneticiliği Program sayıs1 91 olup (Devlet ve vakıf üniversiteleri) bu sayı yeni açılan birimlerle birlikte artış eğiliminde olduğu söylenebilir (YÖK, 2020). Ondokuz Mayıs Üniversitesi Yaşar Doğu Spor Bilimleri Fakültesi Spor Yöneticiliği Lisans programı da 1997 yılında açılmış ve 2009-2010 Akademik Yılı ile birlikte I. ve II. öğretim olmak üzere öğrenci alımı yapmaktadır. Program, özel yetenek sınavı ile öğrenci almakta olup sekiz yarıyılda toplam 240 AKTS'yi tamamlayan öğrenciler mezun edilmektedir. Söz konusu programın 2020 yılı itibari akademik kadrosuna bakıldığındaysa iki profesör, bir doçent, bir doktor öğretim üyesi ve bir öğretim görevlisi bulunmaktadır (Ondokuz Mayıs Üniversitesi, 2020). Programdaki derslerin kategorik dağılımı; genel kültür derslerinin oranı $\% 15,2$; hareket ve antrenman bilgisi \%1,6; spor sağl1k \%5,8; sporda psiko-sosyal alanlar 20,8 ve spor yöneticiliği \%52'dir (Sunay, 2018: 175). Diğer taraftan programdaki staj eğitimi olarak gözüken "Spor Yönetimi Uygulaması" dersi 7 AKTS üzerinden haftalık 3 saat teorik ve 3 saat uygulamalı olarak planlanmıştır. Programın kontenjanı yıl bazından değişkenlik göstermekte olup 2019/20 akademik yılında I. ve II. öğretim olmak üzere toplam 120 öğrencidir. Ayrıca programın yıl bazında değişkenlik gösteren yabancı öğrenci kontenjanı bulunmaktadır. Program çıktılarında; "Beden eğitimi ve spor alanında kuramsal ve uygulamal temel bilgilere sahip olur." ifadesi yer alırken, Türkiye Yükseköğretim Yeterlilikler Çerçevesindeki (TYYÇ) bilgi bölümünde; "Alanındaki güncel bilgileri içeren ders kitapları, uygulama araç-gereçleri ve diğer kaynaklarla desteklenen ileri düzeydeki kuramsal ve uygulamall bilgilere sahip olma.", beceri bölümünde; "Alanında edindiği ileri düzeydeki kuramsal ve uygulamalı bilgileri kullanabilme.", alana özgü yetkinlik bölümünde ise "Alanı ile ilgili verilerin toplanması, yorumlanması, uygulanması ve sonuçlarının duyurulması aşamalarında toplumsal, bilimsel, kültürel ve etik değerlere uygun hareket etme." yeterlikleri konulmuştur (Ondokuz Mayıs Üniversitesi, 2020). Bahsi geçen yeterlikler incelendiğinde öğrencilere, sektörel beklentilere cevap verebilecek bilgi, beceri ve yetkinliklerin kazandırılmas1 hedeflendiği görülmektedir. Nitekim, spor yöneticilerinin yetiştirilmesi süreci ile ilgili bilim insanları, uygulamalara ve deneyimlere dayanan öğrenme-öğretme anlayışının gerekliliğine dikkat çekmektedir. Örneğin Sunay, (1998: 62) spor yöneticisinin sporun sağlıklı olarak yönetiminde önemli bir unsur olduğunu ve spor yöneticilerinin, üniversitelerin Beden Eğitimi ve Spor Yüksekokulu Spor Yöneticiliği programlarında uygulanan kapsamlı bir eğitim programından geçmeleri gerektiğini bildirmektedir. Yetim ve Şenel (2001: 7) ise spor yöneticisinin, pratik deneyimlerini devamlı yenileyerek, bu deneyimleri teorik olarak güçlendirmesi, karmaşık bir yapıya sahip olan sporu ve onun organizasyonuna ilişkin kazanımlar elde etmesi gerektiğine vurgu yapmaktadır. Devecioğlu vd., (2011: 628) ise spor eğitimi veren kurum ve kuruluşların; öğrenenlere, etkili ve verimli bir öğrenme imkânı sağlamasına yönelik olanaklar sunması için gelişim göstermesini ve çalışmalar yapmasını önermektedir. Gündoğdu ve Sunay (2006: 55) ise Spor Yöneticiliği programlarına; öğrenenlere, alanla alakalı sorunları inceleme ve bunlara ilişkin çözümler sunabilme bilgi ve becerisi kazandırabilecek uygulamaların katılabileceğini vurgulamışlardır. O'shea ve Watson, (2007: 64) lisans düzeyinde spor yöneticiliği eğitimi alan öğrencilerin geleneksel eğitim ortamlarında edinilen bilgilerini pratiğe dökebilmesinin önemine dikkat çektiği çalışmasında, öğrenci odaklı aktif öğrenme teknikleriyle daha derin öğrenmeyi sağlama potansiyelinin değerlendirmesini önermektedir. Kandaz-Gelen (2015: 130) araştırmasında, Spor Yöneticiliği eğitim programlarının Spor Yönetimi Akreditasyon Komisyonu (SYAK) standartlarına göre yeterliğini incelemiş ve programın amaçları açısından deneyimsel öğrenme 
sürecinin önemli bir boyut olduğunu tespit etmiştir. Bu çalışmalar, Spor Yöneticiliği eğitiminde deneyimlere dayanan öğrenme-öğretme anlayışının önemli bir özellik olduğuna işaret etmektedir. Kaldı ki, temel ürünü insan ve özellikle de ülkenin bugünleri ve geleceği olan gençler için spor alanında yapılan çalışmaların nicelik ve niteliğini belirleyen; fikir, planlama, uygulama ve raporlama gibi unsurlar bu alanda sorumluluklar üstlenecek spor yöneticilerini zor ve karmaşı bir yapı içerisine düşürebilir. Buradan hareketle; sporun topluma etkileri, spor yönetiminin önemi, spor yöneticilerinin görev ve sorumlulukları, deneyimlere dayalı ögrenme-öğretme faaliyetlerinin mesleki becerilerin kazandırılması ve kalıcı olmasındaki işlevselliği ile akreditasyon kuruluşlarının programlardan beklentileri bağlamında, Spor Yöneticiliği programlarında deneyimsel öğrenme yaklaşımından yararlanılması gerektiği ortadadır.

Sonuç olarak bu araştırmada, Türkiye'de Yükseköğretim Kuruluna bağlı Ondokuz Mayıs Üniversitesi Yaşar Doğu Spor Bilimleri Fakültesi Spor Yöneticiliği lisans programının, öğrenmeöğretme faaliyetlerinde deneyimsel öğrenme yaklaşımını kullanımı bakımından yeterliğinin belirlenmesi amaçlanmıştır.

\section{Literatür değerlendirmesi ve araştırma soruları}

Spor Yöneticiliği programlarında deneyimsel öğrenme yaklaşımının kullanımı, deneyimsel öğrenmenin bilgi, beceri ve yeterlik kazandırmadaki önemi ve işlevi, Spor Yöneticiliği programlarında deneyimsel öğrenme alanları, deneyimsel öğrenme etkinliklerinin Spor Yöneticiliği programı öğrencilerinin kişisel özellikleri üzerindeki etkileri konularında literatürde bazı çalışmalar mevcuttur. Bununla birlikte Spor Yöneticiliği programlarının, deneyimsel öğrenme yaklaşımını kullanımı bakımından yeterliği ile alakalı bir çalıșmaya literatürde rastlanılmamıștır. Dolayısıyla bu araştırmanın sonuçlarının değerlendirmeye alınan programın geliştirilmesi ve sektöre kalifiye spor yöneticililerinin sunulabilmesi açısından önem arz edeceği değerlendirilmektedir.

Araştırma sorularının hazırlanması amacıyla yapılan literatür taraması neticesinde, Spor Yöneticiliği programlarında deneyimsel öğrenme yaklaşımının kullanımı ile ilgili öne çıkan konular başlıklar halinde açıklanarak araştırma sorularına ulaşılmıştır.

\section{Sektör iş birliği}

Akademik programlar öğrenme-öğretme faaliyetlerinde sektör iş birliğine giderek öğrencilerin bilgi, beceri ve yetkinlikleri geliştirecek firsatları sunabilirler (Fathizadeh, 2017: 2). Spor Yöneticiliği programları da spor endüstrisi içerisinde yer alan olası partnerleri ile ilişkilerini güçlendirerek, sektördeki firsatları yakalayabilir ve buradaki deneyimsel öğrenme imkanlarını öğrencilere sunabilir (Brady vd., 2018: 36; Ardahan, 2010: 715). Başarılı sektör iş birliklerine örnek olarak, ortak kurumlarla gerçekleştirilecek proje, program ve ziyaretler gösterilebilir (Colles ve Laderman, 2020: 222-240). Nitekim ilgili literatür incelendiğinde araştırmalar Spor Yöneticiliği programlarının spor sektörünü temsil eden spor örgütleri (kamu-özel), spor organizasyonları, spor yöneticileri ile spor sektörünün farklı kademelerinde yer alan sektör temsilcilileri ile iş birliği halinde olması gerektiğine işaret etmektedir (Devecioğlu, 2005: 3; Çoknaz ve Bulut, 2013: 56; Ardahan, 2010:696; Dees ve Hall, 2012: 71; Schneider ve Stier, 2006: 39; Hardin vd., 2013:43-46; Skinner ve Gilbert, 2007: 125; Jones vd., 2008:87; Johnson, 1995: 2-18; Braunstain-Minkove ve DeLuca, 2015: 15; DeSensi vd., 1990: 31-58). Bu nedenle Spor Yöneticiliği programları için sektör iş birliği program hedeflerine varılması açısından önemli öğrenme-öğretme faaliyeti olarak değerlendirilebilir. Dolayısıyla değerlendirmeye alınan programın "Sektör iş birliği bakımından yeterliği nedir?" sorusuna cevap aranmıştır (S1).

\section{Sınıf dışı ders etkinlikleri}

Deneyimsel öğrenme yaklaşımında, sınıfiçi ders etkinliklerinin yanında kampüs içinde ve dışında yapılacak uygulamalı çalışmalarla öğrenenlere; mesleki bilgi, beceri ve yeterlikleri daha kalıcı olarak kazandırılabilir. Orejan (2018: 2) ders dışı öğrenme etkinlikleri ile birlikte sınıf içinde 
yapılacak deneyimsel öğrenme etkinliklerine katılımın öğrenme sürecine daha yüksek katkı yaptığını bildirmektedir. Bununla birlikte, meslek derslerindeki teorik ders içeriğinin çalışma ortamında pratik uygulamaya dönüştürülmesinin önemi Spor Yöneticiliği programı öğrencilerinin mesleki gelişimini arttırmaktadır (Cuneen ve Parks, 1997: 125-131; Judge vd., 2011: 33). Spor iletişimi alanında giriş seviyesi bir iş için görüştüğünüzde, işveren; güçlü iletişim becerileri geliştirmiş olmanızı ve alanla ilgili deneyim kazanmış olmanızı bekler. Beklenen bu deneyimlerden bazıları; sınıf ortamındaki deneyimsel öğrenme aktiviteleri ile elde edilebilir fakat bu tür uygulamalar sizi sektöre yeteri kadar hazırlamak için yeterli olamayacaktır (Stoldt vd., 2014). Bundan dolayı Spor Yöneticiliği programlarında ders dışı öğrenme etkinliklerinin birtakım deneyimlerle bütünleştirilmesi gerekliliği söz konusudur. Bu sebeple programın "Sınıf dışı deneyimsel öğrenme etkinlikleri bakımından yeterliği nedir?" sorusuna yanitlar aranmıştır (S2).

\section{Staj eğitimi}

Deneyimsel bir öğrenme firsatı olan staj uygulamaları, Spor Yöneticiliği eğitiminde de işlevsel bir alan çalışması sıfatıyla program müfredatlarının önemli bir değişkeni olarak değerlendirilmektedir (Jowdy vd., 2004: 215). Staj eğitimleri, akademik kredi karşılığında, Spor Yöneticiliği eğitim müfredatının bir parçası olarak öğrencilerin spor yönetimi ile ilgili örgütlere gidip söz konusu kuruluşun günlük faaliyetlerine tam anlamıyla ve bütüncül olarak dahil olduğu bir alan çalışmasıdır (Schneider ve Stier, 2006: 36). Resmi bir alt yapıya sahip olan staj programları, müfredatın uygunluğunu değerlendirme ve staj örgütleri ile birlikte programın gücünü belirlemeye imkân tanımaktadır (Ross ve Beggs, 2007: 4). Staj uygulamaları aynı zamanda akademisyenlerin spor organizasyonlarındaki ortaklarla iş birliği yapma ve geliştirme, akademi ile spor işletmeleri arasında ilişkiler kurma ve güçlendirme, spor endüstrisindeki profesyoneller ile araştırmaya dayalı ilişkileri geliştirme ve bununla beraber toplumun ihtiyaçları hakkındaki bilgileri güncelleme firsatlarını da sunabilmektedir (Pauline ve Pauline, 2008: 19). Sonuç olarak Spor Yöneticiliği programları, müfredattaki staj uygulamalarına bütüncül bir yaklaşım göstermeli, staj eğitimi sürecini; planlama, uygulama ve değerlendirme boyutları ile ele alarak öğrencilerin mesleki bilgi ve becerilerinin gelişmesini sağlayacak bir sistem sunması gerektiği söylenebilir. Sonuç olarak, staj eğitiminin öğrencilere mesleki beceriler kazandırabilme potansiyeli önemli görülmüş ve programın "Staj eğitimi bakımından yeterliği nedir?" sorusuna yanıtlar aranmıştır (S3).

\section{Sınıfiçi ders etkinlikleri}

Spor Yöneticiliği eğitimi açısından değerlendirildiğinde, sınıfiçi deneyimsel öğrenme etkinliklerinin, spor yönetiminin uygulama becerisi gerektiren bir alan olması nedeniyle, meslek derslerinde kullanılmasının yararlı olacağı değerlendirilmektedir (Foster ve Dollar, 2010; Zakus vd., 2007: 149). Örneğin Williams ve Parker (2016: 54) bir etkinlik yönetimi dersinde uygulanmış olan liderlik geliştirme faaliyetlerinin etkililiğini incelemiş ve liderlik gelişiminin sınıf içi öğrenme etkinlikleri ile geliştirilebileceğini tespit etmiştir. Lumpkin ve Achen (2015: 9) ise Spor Yöneticiliği eğitiminde, sınıf içinde kullanılan aktif öğrenme etkinliklerinin öğrenci yetenekleri, kurumsal profiller ve içerik zorluğu nedeniyle karmaşık olsa da en azından yarı deneyimsel bir tasarım olarak düşünülebileceğini bildirmektedir. Sınıfiçi öğrenme sürecinde aktif deneyime dayanan birçok teknik kullanılmaktadır. Bunlar; öğrenci sunumları, örnek olay incelemesi, ekip çalışması, sınıfiçi grup tartışmaları, alanla ilgili ziyaretçi konuşmaları, ters-yüz edilmiş sınıf, drama ya da çevrimiçibilgisayar destekli etkinlikler olabilmektedir (Ammar ve Wright, 1999: 184; Young vd., 2008: 2930; Faust ve Paulson, 1998: 14-17; Sattler, 2016: 13; Lumpkin ve Achen, 2015: 1-3). Dolayisiyla, sınıfiçi öğrenme-öğretme faaliyetlerine ilişkin programın bazı yeterlikleri sağlaması gerektiği değerlendirilerek programdaki "Sınıfiçi deneyimsel öğrenme etkinlikleri bakımından yeterliği nedir?" sorusuna yanıtlar aranmıştır (S4). 


\section{Fiziki çevre}

Spor Yöneticiliği eğitim programlarının öğrenme-öğretme faaliyetlerini yürüttüğü yerleşkenin fiziki özellikleri öğrenme sürecinin deneyimselleştirilmesine yardımcı olabilir (Lidon vd., 2011: 301). Tonbul (2013: 98) yükseköğretim kurumlarını aktif öğrenme açısından değerlendirdiği çalışmasında aktif öğrenmeye dayalı sınıflarda geleneksel yaklaşıma zıt olarak oturma düzeninin, öğrenme görevleri ve etkileşim türüne bağlı olarak değişkenlik gösterdiğini bildirmektedir. Güney ve Al-Şensoy (2012: 2337) ise üniversitelerde öğrenme ortamları tasarlanırken bütüncül ve sistemik bir yaklaşım sergilenmesini, bunu yaparken de öğrenme yaklaşımlarına dair hususlara dikkat edilmesini önermektedir. Ek olarak günümüzde e-öğrenme, öğretme faaliyetlerinde hatırı sayılır bir konuma sahip olup öğrencilerin gelișim süreçlerinde deneyimsel öğrenme firsatları sunabilmektedir (Garrett, 2014). Bununla birlikte, sınıf dışı öğrenme aktivitelerine katılım açısından yerleşke içerisinde öğrencilerin aldığı teorik ve uygulamaya dayalı bilgileri deneyimleyebilecek; konferans salonu, spor tesisleri, toplantı odaları gibi fiziki imkanları bulunması gerektiği söylenebilir (Garrett, 2014; Casper ve Pfahl, 2015: 32; Braunstein-Minkove ve Deluca, 2015: 20; West, 2010: 83-84). Bu nedenle, programın bulunduğu yerleşkenin fiziki özelliklerinin öğrencilerin uygulama yapabileceği, başka bir ifade ile mesleki beceriler kazanabilmesinde yaşantısal deneyimler sunabilecek imkanları bulundurması gerektiği değerlendirilmiş ve programın "Fiziki çevre bakımından yeterliği nedir?" sorusuna yanıtlar bulunması hedeflenmiştir (S5).

\section{Rehberlik hizmetleri}

Spor yöneticisi adaylarının spor organizasyonlarında gönüllü olarak görev alması, kariyer hedefleri doğrultusunda iş dünyasına yönlendirilmesi ya da spor sektörü aktörleri ile diyalog kurmasında program ve danışmanlar tarafından sunulan rehberlik hizmetleri belirleyici olabilir. Zira, söz konusu etkinlikler öğrencilerin kariyer hedeflerine varmasında ve mesleki becerilerini geliştirmesinde kolaylaştırıcı rolünde olabilir (Braunstein-Minkove ve Deluca, 2015: 20; Hardin vd., 2013: 50). Bu konuda Southall vd., (2003: 27) spor yönetimi programlarının başarılı olabilmesi için deneyimsel öğrenme firsatlarını artırması gerektiğini bildirmektedir. Nitekim Eratlı-Şirin ve Şahin (2020: 7) rehberlik alan Spor Bilimleri Fakültesi öğrencilerinin başarı şansının almayanlara nazaran 4.046 kat daha fazla olduğunu tespit etmiştir. Spor Yöneticiliği programlarındaki rehberlik hizmetleri sayesinde öğrenciler; kariyer hedefleri oluşturabilir, bu hedeflere ulaşmak için doğru akademik ve deneyimsel programları bulabilir ve mezun olduktan sonra da istihdam elde edebilir (Ross ve McCullough, 2014: 119). Dolayısıyla Spor Yöneticiliği programlarında, öğrencilerin kariyer hedefleri doğrultusunda mesleki beceri ve yeterliklerini geliştirebilecek rehberlik hizmetlerinin sistematik olarak sunulması gerektiği anlaşılmaktadır (Bennett vd., 2003:68). Bundan dolay1 programın "Rehberlik hizmetleri bakımından yeterliği nedir?" sorusuna cevaplar aranmıştır (S6).

\section{Deneyimsel öğrenme çıktısı}

Eyler (2009: 24) ve Pierson ve Troppe (2010: 12-14) deneyimsel öğrenme yöntemleriyle elde edilen öğrenme çıktılarının daha kalıcı olduğunu bildirmektedirler. Yine Cunningham, Sagas, Dixon, Kent ve Turner (2005: 52) staj eğitimine katılan lisans öğrencilerinin mesleki kariyerlerinde daha başarılı olduklarını tespit etmiştir. Straughan, Tay ve Song (2018: 123) ise yaptıkları nitel bir araştırmada spor organizasyonunda görev alan öğrencilerin deneyimleri ve süreçleri yansıtma seviyelerini değerlendirmek amacıyla odak grup görüşmesi yapmışlar; sonuç olarak katılımcıların kişi ve grup yönetimi ile sosyo-duygusal becerilerine yönelik artan farkındalıklar sergilediklerini gözlemlemişler, öğrencilerin de daha derin bir kavrayış gösterdiklerini tespit etmişlerdir. Mcgowan (2017: 43) da yüksek öğretim akademik programlarındaki topluma hizmet uygulamalarının (Service Learning) amaç ve sonuçlarını değerlendirmiş ve sonuçta deneyimsel bir öğrenme firsatı olarak topluma hizmet uygulamalarının program etkinliğini artırdığını tespit etmiş̧lerdir. Spor Yöneticiliği programları, deneyimsel öğrenme tekniklerini müfredatla bütünleştirmeli ve öğrencilerde planlanan 
değişimlerin sağlanıp sağlanmadığını da kontrol etmelidir (Melia, Krishman ve Melia, 2020). Dolayısıyla, programdaki deneyimsel öğrenmeye dayanan öğrenme-öğretme faaliyetlerinin çıktı boyutunda da ele alınması ve buna göre programın geliştirilmesi gerektiği söylenebilir. Bu nedenle değerlendirme alınan programın "Deneyimsel öğrenme çıktıları bakımından yeterliği nedir?" sorusuna yanıt aranmıştır (S7).

\section{Yöntem}

\section{Araştırma deseni}

$\mathrm{Bu}$ araştırma, durum çalışması deseni ile kurgulanmış ve veriler nitel araştırma yöntemlerinden "Görüşme" tekniği ile elde edilmiştir. Creswell (2013) göre durum çalışmasını; araştırmacının belirli bir zaman dilimi ile kısıtlanmış bir durumun çoklu kaynakları kapsayan veri toplama yöntem ve kaynakları (Gözlem, görüşme, görsel-işitseller doküman ve raporlar) ile derinlemesine ele alındığı, durumlara ilişkin temaların tanımlandığ olarak tarif etmektedir. Bu desende, bir durumla alakalı etkenler (Ortam, bireyler, olaylar, süreçler vb.) bütün olarak araştırılır ve bahse konu durumu ne şekilde etkilediği ve mevcut durumdan nasıl etkilendiği üzerine yoğunlaşılır. Bundan dolayı araştırmada, odak grup ve bireysel görüşme teknikleri birlikte kullanılmıştır.

\section{Araştırma Grubu}

Çalışmanın araştırma grubunu belirlemede ölçüt örneklem tekniğinden yararlanılmıştır. Bu tekniğe temel olan anlayış, belirli kriterleri sağlayan bütün hallerin değerlendirilmesidir (Yıldırım ve Şimşek, 2008). Araştırma katılımcılarında aranan ölçütler; odak grup görüşmesi için 4. sınıf öğrencisi olmak, bireysel görüşmeler içinse Spor Yöneticiliği program yöneticisi ve Spor Yöneticiliği meslek öğretim elemanı olmaktır. Araştırmanın amacı doğrultusunda, 2018/19 Akademik Y1lı Bahar Dönemi'nde, Samsun Ondokuz Mayıs Üniversitesi Yaşar Doğu Spor Bilimleri Fakültesi Spor Yöneticiliği lisans programının 4. sınıf öğrencilerinden oluşan 7 kişi ile odak grup görüşmesi, bir program yöneticisi ve bir meslek öğretim elemanı ile de bireysel görüşmeler yapılmıştır. Odak grup katılımcıları, gönüllülük ilkesine göre belirlenmiş ve 3 kadın ve 4 erkek öğrenciden oluşmaktadır. Bireysel görüşme yapılan katılımcılar ise programın kuruluş tarihinden beri aynı programda görev yapmakta olup biri doçent kadrosunda bir diğeri ise profesör kadrosundadır. 4. Sınıf öğrencilerinden odak grup görüşmesi ile veri toplanmasındaki amaç veri zenginliğinin sağlanmasıdır. Diğer taraftan program yöneticileri ve meslek öğretim elemanı ile bireysel görüşme yapılmasındaki amaç program hakkında derinlemesine veri toplanmasıdır. Ayrıca bu iki görüşme tekniği birlikte kullanılarak program hakkında büyük resmin görülmesi hedeflenmiştir (Işık ve Semerci, 2019: 62).

\section{Veri Toplama Aracı}

Çalışmada veriler, araştırma ekibince hazırlanan görüşme formu yöntemiyle elde edilmiştir. Söz konusu veri toplama aracındaki sorular oluşturulmadan önce ilgili literatür incelenmiş ve uzman görüşüne başvurulmuştur. Daha sonra sorular, yarı yapılandırılmış tekniğe dayalı açık uçlu olacak şekilde hazırlanmış, araştırma dışında tutulan bir akademisyen ve bir öğrenci üzerinde test edilerek nihai forma ulaşılmıştır. Katılımcılara yöneltilen sorular programın; "Sektör iş birliği", "Sınıf dış1 öğrenme etkinlikleri", "Staj eğitimi”, "Sınıfiçi öğrenme etkinlikleri", "Fiziki çevre", "Rehberlik hizmetleri" ve "Deneyimsel öğrenme çıktısı" konularındaki yeterlik ve yetersizliklerini belirlemeye yönelik tasarlanmıştır.

\section{Geçerlik ve Güvenirlik}

Çalışma verilerinin geçerlik ve güvenirliği için nitel araştırmalarda kullanılan "İnandırıcılık", "Aktarılabilirlik", "Tutarlık” ve "Teyit edilebilirlik" tekniklerinden yararlanılmıştır (Creswell, 2013; Yıldırım ve Şimşek, 2008). Araştırma verilerinin inandırıcılığı konusunda "Uzun süre etkileşim", "Uzman incelemesi" ve "Katılımcı teyidi” taktikleri kullanılmıştır. Verilerin 
aktarılabilir olmasını sağlamada ise "Amaçlı örneklem" seçimi tercih edilmiştir. Tutarlık için Miles ve Huberman'1n (1994) “Görüş Birliği / (Görüş Birliği+Görüş Ayrıllğı)" tekniği kullanılmış ve \%84 uyum skoru bulunmuştur. "Teyit edilebilirlik" içinse çalışmada toplanan ham veriler araştırmacılar tarafindan arşivlenmiştir.

\section{Verilerin Toplanması}

Veriler, araştırma ekibi tarafindan odak grup görüşmesi ve bireysel görüşme yöntemiyle, Samsun Ondokuz Mayıs Üniversitesi Yaşar Doğu Spor Bilimleri Fakültesi ziyaret edilerek ofis ortamında, katılımcılardan görüşmeler öncesi randevu alınarak toplanmıştır. Görüşmelerde ses kayıt cihazı kullanılmış ve elde edilen ses dosyalarındaki içerik daha sonra MAXQDA programında düz yazı haline getirilmiş̧ir. Odak grup görüşmesi 63 dakika 20 saniye, program yöneticisi ile görüşme 47 dakika 33 saniye ve meslek öğretim elemanı ile görüşme 50 dakika 47 saniye sürmüştür. Görüşme öncesinde, veri toplama aracı için Ondokuz Mayıs Üniversitesi Sosyal ve Beşerî Bilimler Etik kurulundan onay (2018/320) ve ayrıca ilgili birim dekanlığından da yazılı izinler alınmıştır. Katılımcılara, araştırmanın amacı ile ilgili bilgilendirme yapılıış, çalışmanın gönüllü katılıma dayandığ 1 söylenmiş ve her bir katılımcıya bilgilendirilmiş gönüllü olur/onam formu imzalatılmıştır.

\section{Verilerin Analizi}

Verilerin çözümlenmesinde, katılımcılara yöneltilen her bir sorunun bir ana tema olarak değerlendirildiğinden dolayı, "Betimsel analiz" tekniğinden yararlanılmıştır. Bu teknikte veriler, daha önceden belirlenen başlıklar altında (Örneğin temalar) özetlenir ve yorumlanır (Yıldırım ve Şimşek, 2008:86). Bu yöntemde; görüşme tekniği ile toplanan veriler, birbirinden habersiz iki farklı uzmanca deşifre edilmiş, alt temalar ve kodlar belirlenmiştir. Verilerin çözümlenmesindeyse MAXQDA nitel veri analizi programından yararlanılmıştır. Araştırma verileri analiz edilmeden önce odak grup görüşmesi katılımcıları OG, program yöneticisi BG1 ve meslek öğretim elemanı ise BG2 ile isimlendirilerek kimlikleri gizli tutulmuştur.

Her bir temaya ilişkin veriler, araştırmacılar ve okuyucular tarafından kolay anlaşılabilmesi ve yorumlanabilmesi amaciyla "Yeterlikler" ve "Yetersizlikler" olmak üzere iki boyutta sunulmuştur.

\section{Bulgular}

Araştırmanın bu bölümünde, betimsel analiz yöntemiyle çözümlenen veriler yer almaktadır.

Birinci araştırma sorusuna ilişkin (S1) olarak Tablo 1'de katılımcıların "Sektör iş birliği" ile ilgili görüşlerinden elde edilen bulgular yer almaktadır. Programın sektör iş birliği ile ilgili yeterliklerine dair "Etkinlik" alt temasında, yetersizliklerine dairse "İletişim", "İnsan Kaynakları", "İstihdam" ve "Planlama" alt temalarında bulgulara ulaşılmıştır.

Tablo 1: Sektör İş Birliği Bakımından Programın Yeterliğine Dair Görüşler

\begin{tabular}{|c|c|c|c|c|c|}
\hline Tema & $+/-$ & Alt Tema & Kod & $\mathbf{F}$ & Katılım \\
\hline \multirow{6}{*}{$\begin{array}{l}\text { Sektör iş } \\
\text { birliği }\end{array}$} & $\begin{array}{c}\text { Yeterlikler } \\
(+)\end{array}$ & Etkinlik & $\begin{array}{l}\text { Zaman zaman sektörle ortak etkinlikler } \\
\text { yapılıyor. }\end{array}$ & 1 & BG2 \\
\hline & \multirow{5}{*}{$\begin{array}{l}\text { Yetersizlikler } \\
\quad(-)\end{array}$} & \multirow[t]{2}{*}{ İletişim } & $\begin{array}{l}\text { Makro planlamada iletişim eksiklikleri } \\
\text { var. }\end{array}$ & 1 & BG1 \\
\hline & & & Paydaş kurumlarla iletişim sorunları var. & 3 & BG1,BG2 \\
\hline & & $\begin{array}{l}\text { İnsan } \\
\text { Kaynakları }\end{array}$ & $\begin{array}{l}\text { Norm kadro planlaması nedeniyle iş gücü } \\
\text { eksikliği var. }\end{array}$ & 1 & BG2 \\
\hline & & İstihdam & İstihdam alanında belirsizlikler var. & 4 & BG1,BG2 \\
\hline & & Planlama & Sektörle planlı bir iş birliği yok. & 5 & BG1,OG \\
\hline
\end{tabular}

Programın sektör iş birliği bakımından yeterliğine ilişkin bazı görüşler şu şekildedir. BG2 Katılımcıs1, "Sektörle zaman zaman faaliyetler yapıllyor. Organizasyon boyutunda. Bir spor 
organizasyonunda ihtiyaç neyse yöneticidir antrenördür. Sanki bir müsabaka yaşatıllyormuşçasına bazı dersler kapsamında yapıllyor." görüşünü bildirmiştir. Programın yetersizliğine dair iletişim alt temasında BG2 kat1lımcıs1 "Ne tür faaliyetler yürütülüyor bundan bir haberiz. Onlar da burada ne yapıldiğı ile ilgili detaylı bir bilgiye sahip değiller. " görüşünü paylaşırken BG1 katılımcısı ise ayn1 temada "Kamu ve özel sektör anlaminda değerlendirdiğimizde üniversitenin bir problemi gibi gözüküyor. Rektörlük boyutundaki toplantılarda sıkça üniversite ile şehrin ayrı olduğundan bahsediliyor." görüşünü paylaşmıştır. Yine programın sektör ile iş birliği temasındaki yetersizliğine dair "İstihdam" alt temasında BG1; spor kulüplerinin program mezunlarından yararlanmadığına dikkat çekerken BG2 ise Türkiye'de tam anlamıyla bir spor yöneticisi meslek tanımının olmadığ1 vurgusunda bulunmuştur. "Planlama" alt temasında ise BG1, programın spor yöneticileri ile doğrudan bir ilişkisinin olmadığını ve spor kulüpleri ile iş birliklerinin ikili ilişkilerden öteye gidemediğini bildirmiştir. OG katılımcıları ise programın sektörle iş birliğinin olmadığını bildirmişlerdir. Son olarak "İnsan kaynakları" alt temasında ise BG2; "Bunda engellerimiz var. Birincisi öğretim elemanı açısından bir norm kadro sıkıntısı var. Yeteri kadar istihdam edemiyoruz. $B u$, dışarı ile ilişkileri sağlıklı bir zemine oturtma açısından ciddi sorunlar oluşturuyor." ifadesini kullanmıştır.

İkinci araştırma sorusuna ilişkin (S2) Tablo 2'de katılımcıların "Sınıf dış1 öğrenme etkinlikleri" ile ilgili görüşlerinden elde edilen bulgular yer almaktadır. Programın sınıf dışı öğrenme etkinliklerine dair yeterliği ile ilgili "Araştırma" ve "Etkinlik" alt temalarında, yetersizliğine dairse "Müfredat", "Öğrenci profili", "Planlama" ve "Yönetim desteği" alt temalarında bulgular elde edilmiştir.

Tablo 2: Sınıf Dışı Öğrenme Etkinlikleri Bakımından Programın Yeterliğine Dair Görüşler

\begin{tabular}{|c|c|c|c|c|c|}
\hline Tema & $+1-$ & Alt Tema & Kod & $\mathbf{F}$ & Katılım \\
\hline \multirow{17}{*}{$\begin{array}{l}\text { Sınıf dışı } \\
\text { öğrenme } \\
\text { etkinlikleri }\end{array}$} & \multirow{5}{*}{$\begin{array}{l}\text { Yeterlikler } \\
\quad(+)\end{array}$} & Araștırma & Ders dıșı araştırma etkinlikleri yapılıyor. & 2 & BG1,BG2 \\
\hline & & \multirow{4}{*}{ Etkinlik } & Ders dișı etkinlikler uygulamaya dökülüyor. & 1 & BG1 \\
\hline & & & Sektör aktörleri ile çeşitli etkinlikler yapılıyor. & 1 & BG1 \\
\hline & & & $\begin{array}{l}\text { Spor etkinlikleri öğrenciler tarafindan organize } \\
\text { ediliyor. }\end{array}$ & 1 & BG1 \\
\hline & & & $\begin{array}{l}\text { Teorik bilgi uygulamalı etkinliklerle } \\
\text { destekleniyor. }\end{array}$ & 1 & BG2 \\
\hline & \multirow{12}{*}{$\begin{array}{l}\text { Yetersizlikler } \\
\quad(-)\end{array}$} & \multirow{3}{*}{ Müfredat } & $\begin{array}{l}\text { Ders yükünün fazla oluşu etkinlikleri olumsuz } \\
\text { etkiliyor. }\end{array}$ & 2 & $\mathrm{BG} 1, \mathrm{BG} 2$ \\
\hline & & & $\begin{array}{l}\text { Meslek dersleri sektör odaklı araştırmalarla } \\
\text { desteklenmiyor. }\end{array}$ & 1 & BG2 \\
\hline & & & Müfredat daha çok teorik ders odaklı planlamıș. & 2 & OG,BG2 \\
\hline & & \multirow{3}{*}{$\begin{array}{l}\text { Öğrenci } \\
\text { profili }\end{array}$} & $\begin{array}{l}\text { Ders dışı etkinlik noktasında öğrenci } \\
\text { motivasyonu düşük. }\end{array}$ & 1 & OG \\
\hline & & & $\begin{array}{l}\text { Öğrenciler bireysel olarak sorumluluk almak } \\
\text { istemiyor. }\end{array}$ & 1 & OG \\
\hline & & & $\begin{array}{l}\text { Sınıf dışı etkinliklere dair öğrenci farkındalığı } \\
\text { yok. }\end{array}$ & 1 & OG \\
\hline & & \multirow{3}{*}{ Planlama } & Ders dışı etkinlikler sistematik yapılmıyor. & 6 & BG2,OG \\
\hline & & & $\begin{array}{l}\text { Ders dışı etkinliklere katılımda öğrenciler pasif } \\
\text { kalıyor. }\end{array}$ & 1 & OG \\
\hline & & & Okuldaki öğreti genelde teoride kalıyor. & 1 & BG2 \\
\hline & & \multirow{3}{*}{$\begin{array}{l}\text { Yönetim } \\
\text { desteği }\end{array}$} & $\begin{array}{l}\text { Bütçe sorunları ders dışı etkinlikleri olumsuz } \\
\text { etkiliyor. }\end{array}$ & 2 & BG2 \\
\hline & & & $\begin{array}{l}\text { Mevzuat kaynaklı yönetici tutumları olumsuz } \\
\text { etkiliyor. }\end{array}$ & 2 & BG2 \\
\hline & & & Öğrenci kulüpleri yeterince desteklenmiyor. & 1 & BG1 \\
\hline
\end{tabular}


Programın sınıf dışı öğrenme etkinlikleri ile ilgili bazı görüşler şu şekildedir. Programın yeterliği ile ilgili BG1; "Memleketinde periyodik olarak yapılan herhangi bir organizasyonun hangi aşamalardan geçtiğini ögrrenciler rapor olarak sunsunlar şeklide yapıyoruz." görüşünü paylaşırken BG2 ise; "Teknik değil ama gezi anlamında fakülte geneli gezilerimiz var. Bu da bir organizasyonu gerektiriyor ve az da olsa burada öğrencilerimize görev verebiliyoruz." ifadesini kullanmıștır. Etkinlik alt temasında ise BG1; "Mesela bu sene spor organizasyonlart teknikleri dersinde bir hocamı; tıpkı büyük organizasyonlarda olduğu gibi komiteler oluşturmuş ve oralarda da görevler vermişti ve ögrenciler 4 farklı branşta sinıflararası spor organizasyonu düzenlediler. Tenis, yüzme, futbol ve Voleybol branşlarında. Sponsor bulmuşlar. Madalyalar bulmuşlar. Sonuçta öğrenciler bunları kendileri karşılayamaz. Bunlar belki de şunu düşünüyorum. Burada aldlkları teorik bilgilerin bir uygulaması şeklinde dışarlya yansıması şeklinde söyleyebiliriz." ifadesini kullanırken BG2; "Sanki bir müsabaka yaşatılıyormuş̧̧asına bazı dersler kapsamında yapıllyor. Birtakım hocalar tarafindan spor organizasyonlarl dersler kapsaminda. Yani bir organizasyon nasıl yapılır? sorusunu yaşayarak deneyim kazanarak geçiriyorlar.” görüşünü paylaşmıştır. Diğer taraftan programın sınıf dış1 öğrenme etkinlikleri bakımından yetersizliği ile ilgili BG1 ve BG2 katılımc1ları ders yükünün fazla olmasının sınıf dışı öğrenme etkinliklerini planlamada engel oluşturduğunu, müfredatta da daha çok teorik derslerin var olduğunu ve etkinliklerin sistematik olarak yapılmadığını bildirmişlerdir. Ders dışı öğrenme etkinlikleri ile ilgili OG katılımcıları daha çok öğrenci profili alt temasında görüş bildirmiştir. Örneğin katılımcılar "Bununla ilgili şöyle bir şey söyleyeyim. Bireylerin kendilerinde sorumluluk alma gibi bir inisiyatifleri yok artık. Şu şekilde; okulumuz adına bir program yapacağız misal veriyorum. Bir arkadaşıma gittiğim zaman, böyle böyle bir projem var bana bir destek verir misin? desem hiç umursamıyorlar." ifadesi ile öğrencilerin düşük motivasyonlarına dikkat çekmişlerdir. Yönetim desteği alt temasında ise BG1 ve BG2 katılımcıları bütçe ve mevzuat kaynaklı sorun ve eksikliklerin ders dışı öğrenme etkinliklerini olumsuz etkilediğini bildirmişlerdir.

Üçüncü araştırma sorusuna ilişkin (S3) Tablo 3’te katılımcıların "Staj eğitimi” ile ilgili görüşlerinden elde edilen bulgular yer almaktadır. Programın staj eğitimine dair yeterliği ile ilgili "Denetleme" ve "İşyeri Seçimi" alt temalarında, yetersizliğine dairse "Amaç farkındalığı", "Mevzuat", "Öğrenci sayısı", "Protokol” ve Staj işyeri” alt temalarında bulgular elde edilmiştir.

Tablo 3. Staj Eğitimi Bakımından Programın Yeterliğine Dair Görüşler

\begin{tabular}{|c|c|c|c|c|c|}
\hline Tema & $+1-$ & Alt Tema & Kod & $\mathbf{F}$ & Katılım \\
\hline \multirow{10}{*}{$\begin{array}{l}\text { Staj } \\
\text { eğitimi }\end{array}$} & \multirow{2}{*}{$\begin{array}{l}\text { Yeterlikler } \\
(+)\end{array}$} & Denetleme & $\begin{array}{l}\text { Öğrenciler, staj dosyaları üzerinden } \\
\text { periyodik olarak takip ediliyor. }\end{array}$ & 1 & BG1 \\
\hline & & $\begin{array}{l}\text { İşyeri } \\
\text { seçimi }\end{array}$ & Staj işyerini öğrenciler seçebiliyor. & 1 & BG1 \\
\hline & \multirow{8}{*}{$\begin{array}{c}\text { Yetersizlikle } \\
\mathrm{r} \\
(-)\end{array}$} & \multirow{2}{*}{$\begin{array}{l}\text { Amaç } \\
\text { farkındalığ } \\
1\end{array}$} & $\begin{array}{l}\text { Staj eğitimi öğrenciler tarafından formalite } \\
\text { gibi algılanıyor. }\end{array}$ & 1 & OG \\
\hline & & & $\begin{array}{l}\text { Öğrenciler iş yerlerinde amacı dışında } \\
\text { kullanılıyor. }\end{array}$ & 1 & OG \\
\hline & & Mevzuat & Mevzuat kaynaklı sorunlar var. & 6 & $\begin{array}{c}\text { BG1,BG2,O } \\
\text { G }\end{array}$ \\
\hline & & $\begin{array}{l}\text { Öğrenci } \\
\text { sayıs1 }\end{array}$ & $\begin{array}{l}\text { Öğrenci sayısının çokluğu staj sürecini } \\
\text { olumsuz etkiliyor. }\end{array}$ & 1 & BG2 \\
\hline & & Protokol & $\begin{array}{l}\text { Staj işyeri ile okul arasında bir sözleşme } \\
\text { yok. }\end{array}$ & 1 & OG \\
\hline & & \multirow{3}{*}{ Staj işyeri } & Staj iş yerlerinin stajyer politikası yok. & 1 & $\mathrm{OG}$ \\
\hline & & & $\begin{array}{l}\text { Staj işyeri çalışanları bilgi paylaşımına } \\
\text { açık değil. }\end{array}$ & 4 & OG,BG2 \\
\hline & & & $\begin{array}{l}\text { Staj işyeri eğitiminde deneyimleme firsatı } \\
\text { sunulmuyor. }\end{array}$ & 2 & OG \\
\hline
\end{tabular}


Programdaki staj eğitimi ile ilgili bazı görüşler şu şekildedir. Programın yeterliğine ilişkin BG1 kat1lımcıs1 "Denetleme" alt temasında "Bizim her ögrencimizin, buradan staja giderken bizim tarafımızdan hazırlanmış bir dosyası vardır. Haftalık olarak gittiği her birimdeki görevlerini, işleyişi, kendi gözlemlerini ve anlatılanları raporlaştırırlar ve her hafta sorumlu hocasının yanında bunun tartışmasın yaparlar. Bundan geri dönüt alıyoruz." ve "İş yeri seçimi”" alt temasında "Öğrencinin seçebilme imkânı var. İlçelere gidebiliyor. Ya da birinci lig basket takımına gidebiliyor. Öğrencinin tercihi." görüşlerini bildirmiştir. Staj eğitimi ile ilgili yetersizliklere dair katılımcılar birçok görüş bildirmiştir. "Mevzuat" alt temasında tüm katılımcılar, mevzuat kaynaklı sıkıntıları işaret eden ifadelerde bulunmuştur. Örneğin BG1 ve BG2, staj işyerlerinin ücret ödemekten kaçındığını dile getirirken OG katılımcıları ise spor alanında merkezi idareye bağlı kurumların stajyer öğrenci istemediklerini bildirmişler, program ile staj işyeri arasında bir protokol olmadığını söylemişlerdir. OG katılımcıları ayrıca staj eğitiminin öğrenciler tarafından bir mezuniyet formalitesi olarak görüldüğünü, staj eğitimi esnasında da öğrencilerin meslek alanı ile ilgisi olmayan işlerde çalıştırıldıklarını bildirmişlerdir. Son olarak BG2, staj işyerlerindeki personelin bilgi paylaşımına açık olmadığını ve öğrenci sayısının fazla olması nedeniyle staj eğitiminin kalitesinin düştüğünü bildirmiştir.

Dördüncü araştırma sorusuna ilişkin (S4) Tablo 4'te katılımcıların programın "Sınıfiçi öğrenme etkinlikleri” ile ilgili görüşlerinden elde edilen bulgular yer almaktadır. Programın Sınıfiçi öğrenme etkinliklerine dair yeterliği ile ilgili "Aktif öğrenme" alt temasında, yetersizliğine dair ise “Aktif öğrenme", "Müfredat” ve "Öğrenci sayısı" alt temalarında bulgular elde edilmiştir.

Tablo 4: Sınıfiçi Öğrenme Etkinlikleri Bakımından Programın Yeterliğine Dair Görüşler

\begin{tabular}{|c|c|c|c|c|c|}
\hline Tema & $+1-$ & Alt Tema & Kod & $\mathbf{F}$ & Katılım \\
\hline \multirow{6}{*}{$\begin{array}{l}\text { Sinıf içi } \\
\text { öğrenme } \\
\text { etkinlikleri }\end{array}$} & $\underset{(+)}{\text { Yeterlikler }}$ & $\begin{array}{l}\text { Aktif } \\
\text { ögrenme }\end{array}$ & $\begin{array}{l}\text { Aktif öğrenme etkinlikleri az da olsa } \\
\text { yapılıyor. }\end{array}$ & 1 & BG1 \\
\hline & \multirow{5}{*}{$\begin{array}{l}\text { Yetersizlikler } \\
\quad(-)\end{array}$} & \multirow{3}{*}{$\begin{array}{l}\text { Aktif } \\
\text { öğrenme }\end{array}$} & Dersler slayt okuma şeklinde işleniyor. & 3 & OG \\
\hline & & & Öğrenciler aktif olarak derse dahil edilemiyor. & 1 & BG2 \\
\hline & & & $\begin{array}{l}\text { Sinıfiçi aktif öğrenme teknikleri münferiden } \\
\text { kullanıliyor. }\end{array}$ & 3 & OG \\
\hline & & Müfredat & Müfredat teorik dersler üzerine planlanmış. & 1 & OG \\
\hline & & $\begin{array}{l}\text { Öğrenci } \\
\text { sayıs1 }\end{array}$ & $\begin{array}{l}\text { Öğrenci sayısı aktif öğrenmeyi kullanmak } \\
\text { için çok fazla. }\end{array}$ & 3 & BG1,BG2,OG \\
\hline
\end{tabular}

Programın sınıfiçi öğrenme etkinlikleri bakımından yeterliği ile ilgili BG1 katılımcısı; derslerde, aktif öğrenmeye dayalı öğrenme etkinliklerinin az da olsa yapıldığını bildirmiştir. Diğer taraftan aynı alt temadaki yetersizliklere ilişkin BG2; "Öğrencileri aktif olarak derse dahil edebiliyorlar mı? Bence hayır. Edemiyorlar. Bilgiler toplama bir şekilde o kaynaktan bu kaynaktan aktarılıyor. Ama bunun pratik çalışması yok." OG katılımcısı ise "Bazı hocalarımız kısmi olarak aktif ögrenmeyi sağllyor. Bazı hocalarımız şöyle yapıyor. Geliyor slayttan okuyor iki saat gidiyor. Zaten bir saat sonra ben onu unutuyorum. Bazı hocalarımı da aynı şekilde konu anlatıyor." ifadesinde bulunarak derslerde aktif öğrenme tekniklerinin genel olarak uygulanmadığına dikkat çekmiştir. Ayrıca OG katılımcıları müfredatın teorik dersler üzerinde planlandığına vurgu yapmaktadırlar. Son olarak tüm katılımcılar öğrenci sayısının fazla oluşunun sınıf içi öğrenme etkinliklerini olumsuz yönde etkilediğini bildirmiştir.

Beşinci araştırma sorusuna ilişkin (S5) Tablo 5'te katılımcıların "Fiziki çevre" ile ilgili görüşlerinden elde edilen bulgular yer almaktadır. Programın fiziki çevresine dair yeterliği ile ilgili bir görüş elde edilemezken programın yetersizliğine dair "Sınıf düzeni" ve "Uygulama alanları" alt temalarında bulgular elde edilmiştir. 
Tablo 5: Fiziki Çevre Bakımından Programın Yeterliğine Dair Görüşler

\begin{tabular}{|c|c|c|c|c|c|}
\hline Tema & $+/-$ & Alt Tema & Kod & $\mathbf{F}$ & Katılım \\
\hline \multirow{5}{*}{ Fiziki çevre } & \multirow{5}{*}{$\begin{array}{l}\text { Yetersizlikler } \\
(-)\end{array}$} & Sınıf düzeni & $\begin{array}{l}\text { Derslik planlaması aktif öğrenme } \\
\text { etkinliklerine uygun değil. }\end{array}$ & 6 & BG1,BG2,OG \\
\hline & & \multirow{4}{*}{$\begin{array}{l}\text { Uygulama } \\
\text { alanları }\end{array}$} & $\begin{array}{l}\text { Meslek öğretimi için uygulama alanları } \\
\text { yetersiz. }\end{array}$ & 3 & BG1,BG2 \\
\hline & & & $\begin{array}{l}\text { Tesis planlaması bölüm ihtiyaçlarına göre } \\
\text { yapılmıyor. }\end{array}$ & 2 & BG2 \\
\hline & & & $\begin{array}{l}\text { Tesis planlamasında yöneticilik uygulama } \\
\text { alanları düșünülmemiș. }\end{array}$ & 2 & BG2 \\
\hline & & & $\begin{array}{l}\text { Toplantı salonları öğrenci tarafindan aktif } \\
\text { kullanılamıyor. }\end{array}$ & 1 & $\mathrm{OG}$ \\
\hline
\end{tabular}

Programın fiziki çevre bakımından yeterliği ile ilgili katılımcılardan herhangi bir olumlu görüş alınamamıştır. Diğer taraftan katılımcılar, bu temadaki yetersizlikleri ise; "Sınıf düzeni" ve "Uygulama alanları" alt temalarında bildirmişlerdir. Tüm katılımcılar klasik sınıf düzenlerinin öğrenme sürecinin deneyimselleştirilmesine olumsuz etki yaptığını bildirmişlerdir. Programın bulunduğu yerleşkedeki spor yöneticiliği uygulama alanlarının yetersizliği ile ilgili olarak BG2; "Üniversiteler kurulurken fiziki ihtiyacalar da bölümlerin ihtiyaçlarına göre yapılmamaktadır." ve "Bu manada tamamen bizim tesis müştemilatımızın yeterli olduğunu düşünmüyorum. Buna uygun kongre salonları, küçük deneme odaları ve farklı konferans salonlarl gibi alanları oluşturulması gerekir. Bunun çok da maliyeti olmasa da düşünülmediğini değerlendiriyorum." Görüşlerini paylaşırken BG2 ise "Sadece fakülte olarak bir dönem sermayemiz var bu anlamda bir fitness salonumuz var. Orada birkaç ögrenimiz yönetim olarak burada görevlendirebilir. Hani burayı nasıl pazarlarsınız? Belki burada birkaç ögrenci istihdam edilebilir. Bu anlamda çok fazla bir imkânımız olduğunu söyleyemem." görüşünü paylaşmışlardır. Bu alt temada OG katılımcıları ise "Mesela bazı dersler bu toplantı odasından da yapılabilirdi. Öğrenciler burada birbirinin yüzünü görüyor. İnsanın konuşma şekli bile değişiyor. Ama sıra düzeninde kimse kimseyi göremiyor." görüşünü bildirmişlerdir.

Altıncı araştırma sorusuna ilişkin (S6) Tablo 6'da katılımcıların "Rehberlik hizmetleri” ile ilgili görüşlerinden elde edilen bulgular yer almaktadır. Programın rehberlik hizmetlerine dair yeterliği ile ilgili "Danışmanlık", "İletişim", "Oryantasyon" ve "Yönlendirme" alt temalarında; yetersizliğine dair ise "Danışmanlık", "Kariyer planlaması", "Öğrenci sayısı" ve "Yönlendirme" alt temalarında bulgular elde edilmiştir.

Tablo 6: Rehberlik Hizmetleri Bakımından Programın Yeterliğine Dair Görüşler

\begin{tabular}{|c|c|c|c|c|c|}
\hline Tema & $+/-$ & Alt Tema & Kod & $\mathbf{F}$ & Katılım \\
\hline \multirow{9}{*}{$\begin{array}{l}\text { Rehberlik } \\
\text { hizmetleri }\end{array}$} & \multirow{4}{*}{$\begin{array}{l}\text { Yeterlikler } \\
\qquad(+)\end{array}$} & Danışmanlık & Danışman hocalar bireysel olarak ilgileniyor. & 2 & BG1,BG2 \\
\hline & & İletişim & Akademik personel birebirde yardımcı oluyor. & 3 & BG1,BG2,OG \\
\hline & & Oryantasyon & $\begin{array}{l}\text { Yeni öğrencilere oryantasyon toplantısı } \\
\text { yapıllyor. }\end{array}$ & 2 & BG1,BG2 \\
\hline & & Yönlendirme & Sektöre yönlendirme yapılıyor. & 2 & BG1,OG \\
\hline & \multirow{5}{*}{$\begin{array}{c}\text { Yetersizlikler } \\
(-)\end{array}$} & Danışmanlık & $\begin{array}{l}\text { Danışmanlık sistemi çoğunlukla ders kayıtları } \\
\text { ile sınırlı. }\end{array}$ & 4 & $\mathrm{BG} 1, \mathrm{BG} 2, \mathrm{OG}$ \\
\hline & & $\begin{array}{l}\text { Kariyer } \\
\text { planlaması }\end{array}$ & Kariyer planlaması yapılmıyor. & 4 & BG1,BG2,OG \\
\hline & & Öğrenci sayısı & Öğrenci sayısını fazla. & 1 & BG2 \\
\hline & & Yönlendirme & $\begin{array}{l}\text { Spor organizasyonuna yönlendirmeler sürekli } \\
\text { yapılmıyor. }\end{array}$ & 1 & BG2 \\
\hline & & & Spor kulüplerine yönlendirme yapılmıyor & 1 & OG \\
\hline
\end{tabular}

Programın rehberlik hizmetleri bakımından yeterliği ile ilgili birçok olumlu görüş elde edilmiştir. "Danışmanlık" alt temasında BG1 ve BG2 katılımcıları, sınıf danışmanı olan hocaların bireysel olarak öğrencilerle ilgilendiklerini dile getirirken "İletişim" alt temasında ise tüm 
katılımcılar, programdaki akademik personelin birebirde öğrencilerle ilgilendiklerini ifade etmişlerdir. Ayrıca BG1 ve BG2 katılımcıları, programa yeni başlayan öğrencilere yönelik oryantasyon toplantısı yapıldığını bildirmişlerdir. "Yönlendirme" alt temasında ise BG1; "Buradan sadece spor yöneticiliği diploması alıp değil ben sizi bir bütün olarak ele alıyorum. Spor adamısınız siz diyorum. Bence spor yöneticisi değilsiniz. Spor adamı nedir? Aynı zamanda iyi bir antrenör, iyi bir ögretmen iyi bir yöneticidir. Iyi bir rekreasyon lideridir. Bunların hepsini iyi bilmelisiniz. Dolayısı ile alanınızla alakalı ilgi duyduğunuz alanda; hakemlik, antrenörlük belgesi kurslarına ya da diğer eğitimlere mutlaka katılın. Bu size, hem deneyim kazandıracak hem de gelir kazandıracak şeyler olacaktır, şeklinde yönlendiriyorum." ifadesini kullanırken OG katılımcıları "Bazı hocalarımız ciddi anlamda bizim bir şeyler öğrenmemiz için yönlendiriyor." görüşünü paylaşmışlardır. Programın rehberlik hizmetleri bağlamındaki yetersizliklerine ilişkin olarak tüm katılımcıların sınıf danışmanlığı ile ilgili olarak verilen rehberliğin çoğunlukla ders kayıtları ile sınırlı kaldığına dikkat çekmişlerdir. Yine tüm katılımcılar programın öğrencilere bir kariyer planlaması sunamadığını bildirmişlerdir. Programdaki yetersizliklere ilişkin BG2; "Öğrenci sayısı" alt temasında rehberlik hizmetleri ile ilgili olarak "Hocalar buna istekli midir? Öğrenci sayısı çok fazla. Yani hocalar da bunu bir angarya olarak görebilmektedir. Bu biraz da kültürle alakalıdır." ifadesini paylaşırken "Yönlendirme" alt temasında ise OG katılımcısı "Spor organizasyonları konusunda bir rehberlik yapılabilir ama olmuyor. Burada engelliler olimpiyat oyunlarl yapıldl. Orada görev aldık. Bir olimpiyatın nasıl gerçekleştirilemeyeceğini anladım. Maç sonunda sporculara vişne suyu veriliyor! Buradan hocalar yönlendirmişti. Ben de buradaydım. Yaz döneminde. Ama bu konuda hocalar bize adeta yalvarmıştı. Sizin alanınızla ilgili demişti. Ama bunların daha çok yapılması gerekiyor. Bu büyük organizasyonlar değil de her türlü organizasyona yönlendirmeleri gerekir." düşüncesini vurgulayarak yönlendirmelerin daha çok olması gerektiğini bildirmiştir.

Yedinci araştırma sorusuna ilişkin (S7) Tablo 7'de katılımcıların "Deneyimsel öğrenme çıktısı" teması ile ilgili görüşlerinden elde edilen bulgular yer almaktadır. Programın deneyimsel öğrenme çıktılarına dair yeterliği ile ilgili "İstihdam" ve "Deneyim kazanma" alt temalarında, yetersizliğine dair "Müfredat”, "Öğrenci profili”, "İşyeri deneyimi”, "Uygulama alanı” ve "Yeterlik" alt temalarında bulgular elde edilmiştir.

Tablo 7: Deneyimsel Öğrenme Çıktısı Bakımından Programın Yeterliğine Dair Görüşler

\begin{tabular}{|c|c|c|c|c|c|}
\hline Tema & $+/-$ & Alt Tema & Kod & $\mathbf{F}$ & Katılım \\
\hline \multirow{8}{*}{$\begin{array}{l}\text { Deneyimsel } \\
\text { öğrenme } \\
\text { çıktısı }\end{array}$} & \multirow{2}{*}{$\begin{array}{l}\text { Yeterlikler } \\
\qquad(+)\end{array}$} & İstihdam & $\begin{array}{l}\text { Staj uygulaması istihdam şansını } \\
\text { artırıyor. }\end{array}$ & 1 & BG1 \\
\hline & & $\begin{array}{l}\text { Deneyim } \\
\text { kazanma }\end{array}$ & $\begin{array}{l}\text { Staj eğitimi öğrenme deneyimi } \\
\text { sunuyor. }\end{array}$ & 2 & BG1,BG2 \\
\hline & \multirow{6}{*}{$\begin{array}{l}\text { Yetersizlikler } \\
\quad(-)\end{array}$} & \multirow{2}{*}{ Müfredat } & $\begin{array}{l}\text { Müfredat sektör beklentilerine uygun } \\
\text { değil. }\end{array}$ & 1 & BG2 \\
\hline & & & $\begin{array}{l}\text { Müfredat bütünlüğü ile teori ve } \\
\text { uygulama uyumlu değil. }\end{array}$ & 1 & BG2 \\
\hline & & $\begin{array}{l}\text { İşyeri } \\
\text { deneyimi }\end{array}$ & $\begin{array}{l}\text { Staj işyeri yeteri kadar öğrenme } \\
\text { deneyimi sunamiyor. }\end{array}$ & 2 & OG \\
\hline & & \multirow{2}{*}{$\begin{array}{l}\text { Uygulama } \\
\text { alanı }\end{array}$} & $\begin{array}{l}\text { Usta çırak ilişkisinin sağlayacak } \\
\text { örgütsel imkanlar eksik. }\end{array}$ & 1 & BG2 \\
\hline & & & $\begin{array}{l}\text { Uygulama alanı eksikliği öğrenme } \\
\text { çıktısını olumsuz etkiliyor. }\end{array}$ & 1 & BG2 \\
\hline & & Yeterlik & $\begin{array}{l}\text { Sektör beklentilerini karşılayacak } \\
\text { becerilere sahip değiliz. }\end{array}$ & 1 & OG \\
\hline
\end{tabular}

Programın sunduğu deneyimsel öğrenme çıtısı bakımından yeterliği ile ilgili BG1 katılımcısı; staj eğitiminin öğrencilerin istihdam edilebilirliklerini artırdığına dikkat çekerken, yine BG1 ile BG2 ise staj eğitiminin öğrenciler için iyi bir deneyim kazanma alanı olduğunu 
vurgulamışlardır. Deneyimsel öğrenme çıktısı bakımından programın yetersizliği ile alakalı olarak Müfredat alt temasında BG2 müfredatın sektör beklentilerine uygun olmadığını ve yine müfredatın teori ve uygulama uyumunun bulunmadığına vurgu yapmıştır. "İşyeri deneyimi" alt temasında OG katılımcısı; "Şöyle bir örnek vereyim. Tesisler şube müdürlügü diye bir bölüm var. Dosyayı verdim imza attılar. Benim aklımdaki şuydu. Oraya gitmeden önce misal kaç kişi var tesise gelen? 5-10 kişi. Orada bir araç bizi tesisi götürebilir. Tesis nasıl yapıldı? Çimin altındaki zemin nedir? Bunlar yapılırken neler uygulandı? Oradaki abi bana dedi ki. Biz mühendisiz. Inşaatçıyız. Ama en azından bizi oraya götürüp tesiste neler yapılır? Bakımı nasıl yapılır? Arasındaki iletişim nasıl yapılır? Göstermeleri gerekiyor. Bana bir A4 kâğıdı verdiler. Oku buradan dedi. Ondan sonra Allah kerim dedi. Şimdi bir yönetici olduğum zaman misalen bana deseler ki bir tesis yap. Ben o tesisi yapmak için birçok araştırma yapmam lazım zaman kaybl" görüşünü paylaşmıştır. "Uygulama alanı" alt temasında BG2 programda usta-çırak ilişkisini sağlayacak imkanların eksik olduğunu ve uygulama alanı eksikliğinin de öğrenme çıktısını olumsuz etkilediğini bildirmiştir. Son olarak OG katılımcısı "Genel olarak sektörün beklentilerine sahip yeterliklere sahip olduğumuzu düşünmüyoruz." görüşünü paylaşarak deneyimsel öğrenme çıktısı bakımından olumsuz görüş bildirmiştir.

\section{Tartışma ve Sonuç}

Bu bölümde; araştırma bulguları doğrultusunda Ondokuz Mayıs Üniversitesi Yaşar Doğu Spor Bilimleri Fakültesi Spor Yöneticiliği lisans programının deneyimsel öğrenme yaklaşımını kullanımı bakımından yeterliği ve yetersizliğine ilişkin sonuçlar, her bir araştırma sorusu üzerinden literatürdeki çalışmalarla birlikte değerlendirilerek tartışılmıştır.

Çalışmanın birinci sorusunda (S1) programın sektör iş birliğine dair katılımcı görüşleri incelenmiştir. Programın yetersizliği ile ilgili görüşler "İletişsim", "İnsan Kaynakları", "İstihdam" ve "Planlama" temalarında gerçekleşirken sadece "Etkinlik" temasında sektörde zaman zaman etkinliklerin yapıldığı yönünde görüş elde edilmiştir. Üniversiteler ve akademik programların sektörle iș birliği halinde olması öteden beri akademik yazında ve farklı yönetim birimlerinde dile getirilmektedir (Yalçıntaş, 2014: 83). Sektör iş birliğini Spor Yöneticiliği programları açısından ele aldığımızdaysa yapılan çalışmalarda programın mutlak suretle sektörle diyalog halinde olması önerilmektedir (Devecioğlu, 2005: 3; Çoknaz ve Bulut, 2013: 56; Ardahan, 2010: 696; Dees ve Hall, 2012: 71; Schneider ve Stier, 2006: 39). Örneğin Ferkins, (2002: 33) iş yaşantısına dayalı öğrenme faaliyetlerinin, spor örgütleri ile program arasında simbiyotik bir ilişki doğurduğunu bildirirken sektörle iş birliğinin önemine dikkat çekmektedir. Araştırma bulguları incelendiğinde, programın sektörle iş birliğinin yetersiz olduğu anlaşılmakta ve bunun da programdaki insan kaynakları eksikliği, istihdam alanındaki belirsizlikler ve spor sektörü ile yaşanan iletişim eksikliklerinden kaynaklandığı görülmektedir. Burada programın sektörle iş birliğini sistematize edecek önlemlerin alınması gerektiği anlaşılmaktadır. Parent ve Harvey (2009: 27) çalışmasında, Spor Yöneticiliği programları için ortaklık modelini dizayn etmiştir. Bu modelde, üç aşama söz konusudur. Birinci aşamada amaçların belirlenmesi, çevresel analizin yapılması, partner motivasyonlarının durumunun belirlenmesi ve ortaklığın planlanması gerektiği vurgulanmaktadır. İkinci aşamada ise ortaklığın yönetim süreci; ortaklığın sorumluluk, koordinasyon, güven, örgütsel kimlik, örgütsel öğrenme, karşılıklılık, sinerji ve personel özellikleri bakımından özelliklerinin belirlenerek kararların verilmesine dikkat çekilmiştir. Son olarak değerlendirme aşamasındaysa, değerlendirme yöntemi seçilerek çıktılara ilişkin başarım durumunun belirlenmesi söz konusudur. Buradan hareketle değerlendirmeye alınan programın sektör iş birliğinin geliştirilmesi bütüncül bir yaklaşımla ele alarak programın sektörle ilişkileri sistematize edilebilir ve böylelikle de öğrenme çıktılarına katkı sağlanabilir. 
Çalışmanın ikinci sorusunda (S2) programın sınıf dış1 öğrenme etkinlikleri ile ilgili katılımcı görüşleri incelenmiştir. Sınıf dışı öğrenme etkinlikleri, spor yöneticisi adaylarının ilgi alanlarındaki liderlik, girişimcilik, yenilikçilik gibi özelliklerinin geliştirilmesi ve bu süreçte de sektörle bütünleşmesine katkı verebilmektedir (Jowdy vd., 2004: 230). Spor Yöneticiliği programlarında ders dışı öğrenme etkinliği olarak uygulanabilecek farklı yöntemler bulunmaktadır. Bunlar; spor organizasyonlarına gönüllü olarak görev alma, topluma hizmet uygulamaları (Service learning), spor örgütlerine ve tesislerine teknik ziyaretler, rol model kişilerle söyleşirler, gönüllü/yarı zamanlı/tam zamanlı olarak bir spor örgütünde çalışma veya proje odaklı etkinliklere katılım şeklinde olabilmektedir (Foster ve Dollar, 2010: 9-10; Schneider ve Stier, 2006: 40; Brady vd., 2018: 37-38; Diacin, 2018: 115; Efstratia, 2014: 1259; Judge vd., 2011: 34-37; West, 2010: 84; Bennett vd., 2003: 68). Araştırma bulguları incelendiğinde, bu temada programın yeterliği ile ilgili "Araştırma" ve "Etkinlik" alt temalarında olumlu görüşlere rastlanmıştır. Öğrencilerin ders dışı araştırmaya dayalı etkinliklere dahil edildiği ve sektör aktörleri ile etkinlikler yapıldığı, spor etkinliklerinin öğrenciler tarafından organize edildiği ve teorik bilgilerin uygulamalı etkinliklerle desteklendiği yönünde görüşler elde edilmiştir. Diğer taraftan sınıf dışı öğrenme etkinliklerinin yetersizliği ile ilgili olarak "Müfredat", "Öğrenci profili", "Planlama" ve "Yönetim desteğì" alt temalarında görüşler elde edilmiştir. Müfredatla ilgili olarak ders yükünün fazla oluşu, meslek derslerinin sektör odaklı araştırmalarla desteklenmemesi ve müfredatın da daha çok teorik derslere yönelik planlandığını bildirmişlerdir. Öğrenci profili açısından sınıf dışı öğrenme etkinlikleri değerlendirildiğinde, öğrencilerin sorumluluk alma, farkındalık ve motivasyon noktasında yetersizlikleri olduğu görülmektedir. Planlama alt temasında ise ders dışı etkinliklerin sistematik olarak yapılmadığına ilişkin birçok görüş bildirilirken, öğretinin genelde teoride kaldığı ve öğrencilerin bu noktada pasif dinleyici olduğu anlaşılmaktadır. Son olarak sınıf dışı öğrenme etkinlikleri ile ilgili yönetim desteği açısından bütçe sorunları, mevzuat kaynaklı zorluklar ve öğrenci kulüplerinin yeterince desteklenmediği bulgusu elde edilmiştir. Bulgular değerlendirildiğinde sınıf dışı öğrenme etkinlikleri ile ilgili bazı gayretlerin olduğu görülse de bunun arzu edilen düzeyde sistemli olarak gerçekleşmediği anlaşılmaktadır. Oysaki Spor Yöneticiliği programlarında, öğrencilerin spor endüstrisinin beklentilerine cevap verebilecek becerileri kazanabilmesi için, öğrencilerin kariyer hedefleri doğrultusunda alana yönelik çalışmalarının sistematik olarak planlanması ve bu etkinliklerle program müfredatının uyumlu hale getirilmesi önemlidir (Foster ve Dollar, 2010). Dolayısıyla program müfredatının sınıf dışı öğrenme etkinliklerini de kapsayacak şekilde planlanması ve gerekli yönetsel desteklerin sağlanmasının hedeflenen öğrenme çıktılarına varılması için faydalı olacağı söylenebilir.

Çalışmanın üçüncü sorusunda (S3) programdaki staj eğitimi ile ilgili katılımcı görüşleri incelenmiştir. Deneyimsel bir öğrenme firsatı olan staj uygulamaları Spor Yöneticiliği eğitiminde işlevsel bir alan çalışması olarak program müfredatlarının önemli bir değişkenidir (Jowdy vd., 2004: 215). Staj uygulamaları aynı zamanda akademisyenlerin spor organizasyonlarındaki ortaklarla iş birliği yapma ve geliştirme, akademi ile spor işletmeleri arasında ilişkiler kurma ve güçlendirme, spor endüstrisindeki profesyoneller ile araştırmaya dayalı ilişkileri geliştirme ve bununla beraber toplumun ihtiyaçları hakkındaki bilgileri güncelleme fırsatlarını da sunabilmektedir (Pauline ve Pauline, 2008: 19). Bu temadaki bulgular incelendiğinde; programın yeterliği ile ilgili olarak, öğrencilerin staj iş yerini seçimi noktasında serbest olduğu ve staj eğitiminin program tarafindan staj dosyaları üzerinden periyodik olarak izlendiği dile getirilmiştir. Buna karşın staj eğitimindeki yetersizliklere ilişkin pekçok bulguya ulaşılmıştır. Örneğin staj eğitiminin öğrenciler tarafından bir formalite olarak görüldüğü ve aynı zamanda da staj eğitimine giden öğrencilerin kurumlarda Spor Yöneticiliği ile ilgili işler dışında çalıştırıldığ 1 görüşü elde edilmiştir. Diğer taraftan yoğun bir katılımla staj eğitiminin önündeki mevzuat kaynaklı sorunlara dikkat çekilmiştir. Ayrıca staj işyerleri ile program arasında bir protokolün olmadığı ve programdaki öğrenci sayısının fazla olmasının staj işyerlerindeki görevlendirme açısından sorunlar çıkardığı söylenmektedir. Son olarak staj işyerlerinin stajyer öğrencilerle ilgili bir politikasının olmadığı, staj işyerlerindeki çalışanların bilgi 
paylaşımına kapalı olduğu ve öğrencilere staj işyerlerinde meslekle ilgili deneyimleme şansının verilmediği bildirilmiştir. $\mathrm{Bu}$ temadaki bulgular birlikte değerlendirildiğinde, öğrenenler için deneyimsel bir öğrenme alanı olarak programdaki staj eğitiminin yeterli olmadığı söylenebilir. Schneider ve Stier (2006: 40) Spor Yöneticiliği programlarındaki staj eğitimi için, öğrenme hedeflerinin belirlenmesini ve staj sürecinin program staj koordinatörlüğü ve staj iş yeri danışmanları tarafından denetlenmesini, staj eğitiminde stajyerlere zamanında ve uygun işler verilmesini ve staj denetçisinin sürekli (günlük) gözetim ve rehberlik yapmasını önermektedir. Ayrıca, staj eğitiminin yerinde denetim otoritesinin, öğrencinin staj hedeflerine ulaşmasına yardımcı olmak ve aynı zamanda öğrenciye staj boyunca bir mentör olarak hizmet etmek için var olduğunu ve burada sistematik bir program geliştirmek ve uygulamak için öğrenciyle birlikte çalışmaktan sorumlu olduğunu vurgulamaktadır. Dolayısıyla staj süreci içinde yer alan denetçi, staj sürecinde öğrencinin "Öğretmeni” olarak görev yapar ve denetiminin kalitesi, öğrencinin deneyimini büyük ölçüde etkiler (Schneider ve Stier, 2006: 39). Bu bağlamda, programdaki staj eğitiminin hem program hem de staj işyeri tarafından daha iyi gözetim altında tutulması gerektiği söylenebilir. Ayrıca staj eğitiminde mevzuat kaynaklı sorunlar tüm akademik programların ortak sorunudur. Bu konuda program ile işyeri arasında yapılacak protokollerle ilgili mevzuat ve staj işyerlerinden kaynaklı sorunlar aşılabilir. Ayrıca programdaki ögrenci sayısının fazla olması sebebiyle meydana gelen koordinasyon sorunları da staj işyerleri ile yapılacak protokollerle kontrol edilebilir düzeye getirebilir.

Çalışmanın dördüncü sorusunda (S4) programın sınıfiçi öğrenme etkinlikleri ile ilgili katılımcı görüşleri incelenmiştir. Sınıfiçi deneyimsel öğrenme etkinlikleri, Spor Yöneticiliği eğitimi açısından değerlendirildiğinde, spor yönetiminin uygulama becerisi gerektiren bir alan olması nedeniyle, meslek derslerinde kullanılmasının yararlı olacağı değerlendirilmektedir (Foster ve Dollar, 2010; Zakus vd., 2007; 149; Foster ve Dollar, 2010; Williams ve Parker, 2016: 54). Lumpkin ve Achen (2015: 9) Spor Yöneticiliği eğitiminde sınıfta kullanılan aktif öğrenme etkinliklerinin öğrenci yetenekleri, kurumsal profiller ve içerik zorluğu nedeniyle karmaşık olsa da en azından yarı deneyimsel bir tasarım olarak düşünülebileceğini bildirmektedir. Sınıfiçi öğrenme etkinlikleri bakımından, programın yeterliği ile ilgili aktif öğrenme etkinliklerinin derslerde az da olsa yapıldığı ile ilgili görüsşe ulaşılırken programın yetersizliği ile ilgili olarak derslerin slayt okuma şeklinde tamamlandığ tekniklerinin münferiden uygulandığı yönünde görüşlere ulaşılmıştır. Diğer yandan müfredatın teorik derslere odaklı planlandığı ve sınıf mevcudunun aktif öğrenme tekniklerini uygulamak için çok fazla olduğuna dair görüşler de elde edilmiştir. Bu sebeple programın, sınıfiçi öğrenme etkinliklerinde aktif öğrenme tekniklerinin yeterince uygulanamadığı söylenebilir. Dolayısıyla bilhassa spor yöneticiliği meslek derslerinin bölünerek sınıf mevcudunun azaltılması, meslek derslerinde aktif öğrenme tekniklerinin uygulanmasına yönelik öğretim elemanlarına bazı formasyonların verilmesi marifetiyle derslerde öğrenenlerin daha aktif olması sağlanabilir.

Çalışmanın beşinci sorusunda (S5) programın fiziki çevresi ile ilgili katılımcı görüşleri incelenmiştir. Spor yöneticiliği eğitim programlarının öğrenme-öğretme faaliyetlerini yürüttüğü yerleşkenin fiziki özellikleri öğrenme sürecinin deneyimselleştirilmesine yardımcı olabilir (Lidon vd., 2011: 301). Tonbul (2013: 98) yükseköğretim kurumlarını aktif öğrenme açısından değerlendirdiği çalışmasında aktif öğrenmeye dayalı sınıflarda geleneksel yaklaşıma zit olarak oturma düzeninin, öğrenme görevleri ve etkileşim türüne bağlı olarak değişkenlik gösterdiğini bildirmektedir. Güney ve Al-Şensoy (2012: 2337) ise üniversitelerde öğrenme ortamları tasarlanırken bütüncül ve sistemik bir yaklaşım sergilenmesini bunu yaparken de öğrenme yaklaşımlarına dair hususlara dikkat edilmesini önermektedir. Araştırma bulguları incelendiğinde katılımcıların, programın yeterliğine dair bir görüş bildirmemiştir. Buna karşın programın sınıf düzeninin deneyimsel öğrenme odaklı etkinlikler için uygun olmadığı ve yerleşkenin spor yöneticiliği uygulama alanlanı bakımından bazı yetersizliklerinin olduğunu bildirilmiştir. $\mathrm{Bu}$ bağlamda programın, öğrencilere deneyimsel öğrenme firsatları sunabilecek fiziki imkanlarının 
yetersiz olduğu söylenebilir. Bu sebeple, programın kullandığı dersliklerin aktif öğrenme tekniklerinin uygulanabilmesine yönelik planlanması, yerleşke içerisindeki konferans salonu, toplantı odası ve öğrenci kulübü çalışmalarında kullanılabilecek fiziki imkanların oluşturulması, bu imkanlar mevcutsa da aktif kullanımının sağlanması önerilebilir.

Çalışmanın altıncı sorusunda (S6) programın rehberlik hizmetleri ile ilgili katılımcı görüşleri incelenmiştir. Bu temada programın sağladığı yeterlik ve yetersizliklere ilişkin pekçok bulgu elde edilmiştir. Programın yeterliği noktasında danışmanlık ve iletişim yönünden akademik personelin birebirde öğrencilere yardımcı oldukları görülürken sektöre de yönlendirmelerin yapıldığ görüşlerine ulaşılmıştır. Ayrıca programa yeni kayıt olan öğrencilere yönelik oryantasyon toplantılarının yapıldığı söylenmiştir. Diğer taraftan programın yetersizliği ile ilgili olarak danışmanlık hizmetinin ders kayıtlarının takip edilmesinden öteye gidemediği, öğrencilere bir kariyer planlama hizmeti verilmediği sektöre yönlendirmelerin de süreklilik arz etmediği bulguları toplanmıştır. Ayrıca burada yine programdaki öğrenci sayısının fazla olmasının rehberlik hizmetlerinin önünde engel olduğu yorumu yapılmıştır. Bu temadaki yeterlik ve yetersizliklere dair bulgular birlikte değerlendirildiğinde, akademik personelin birebirde öğrencilerle iletişime açık olduğu ve rehberlik yapabildiği söylenebilse de programın sistemli bir şekilde rehberlik hizmeti sunamadığı anlaşılmaktadır. Oysaki programda sunulacak etkili rehberlik hizmetleri ile öğrencilerin kariyer hedeflerine varmasına ve mesleki becerilerini geliştirmesine katkı sağlanabilir (BraunsteinMinkove ve Deluca, 2015: 20; Hardin vd., 2013: 50). Nitekim Eratl1-Şirin ve Şahin (2020: 7) rehberlik alan spor bilimleri fakültesi öğrencilerinin başarı şansının almayanlara nazaran 4.046 kat daha fazla olduğunu tespit etmiştir. Bundan dolayı programdaki rehberlik hizmetlerinin etkili olabilmesi için sınıf danışmanlıklarının yanında öğrencilerin kariyer hedefleri doğrultusunda ilgili akademik personel üzerinden bireysel rehberlik hizmetleri sunulabilir, üniversite rehberlik servisleri ile iş birliğine gidilebilir, kariyer fırsatları noktasında spor sektörü ile ortaklıklar geliştirilerek programın etkinliği artırılabilir.

Araştırmanın yedinci sorusunda (S7) ise programın deneyimsel öğrenme çıktısı ile ilgili katılımcı görüşleri incelenmiştir. Deneyimsel öğrenme yaklaşımına dayalı öğrenme etkinlikleri öğrencilerin, içsel öğrenme memnuniyetini ve ders materyallerinin daha iyi anlaşılmasını ve kalıcılığını arttırmakta, öğrencilerin sürekli öğrenen olma arzusunu ve yeteneğini, kişiler arası iletişimini, problem çözme, analitik ve eleştirel düşünme yetenek ve becerilerini geliştirmektedir (Brickner ve Etter, 2008: 87). Deneyimsel öğrenme etkinlikleri, Spor Yöneticiliği akademik programları açısından ele alındığında öğrencilere bilgi, beceri ve yeterlikleri kazandırmak, kariyer hedefleri doğrultusunda sektörle etkileşimini arttırmak, liderlik, girişimcilik gibi bireysel özelliklerini geliştirmek amacıyla yapılabilmektedir. Bu nedenle öğrencilerde arzulanan değişimlerin sağlanması, bir başka deyişle hedeflenen öğrenme çıtıllarına varılması gerekmektedir. Literatürde yapılan çalışmalar, deneyimsel öğrenmeye dayalı öğrenme etkinliklerinin öğrencilerde olumlu değişimlere sebep olduğunu göstermektedir (Eyler, 2009: 24; Pierson ve Troppe, 2010: 12-14; Cunningham vd., 2005: 52; Straughan vd., 2018: 123). Öğrenenlerin, teorik bilgiyi aldıktan sonra öğrendiklerini henüz unutmadan deneyimlemesi, kalıcılığı sağlayabildiği gibi deneyimlere dayanan öğretiler diğer kişisel özelliklerinin de gelişmesine katk1 verebilir. Bu bağlamda programın deneyimsel öğrenme çıktısı bakımından yeterliği ile ilgili olarak; staj eğitiminin öğrencilerin istihdam oranını artırdığı ve öğrencilere deneyimleyerek öğrenme şansını sunduğu bulgusuna ulaşılmıştır. Öte yandan programın yetersizliklerine ilişkin olarak; müfredatın sektör beklentilerine uygun olmadığı ve dolayısı ile teorik ve uygulama arasındaki bağlantının sağlanamadığı, öğrencilerin staj eğitiminde arzu ettikleri öğrenme deneyimini yaşayamadıkları, programın barındırdığı uygulama alanları bakımından örgütsel eksiklikler olduğu ve bunların da öğrenme çıtısını olumsuz yönde etkilediğine, öğrencilerin de sektörel beklentilerine cevap verebilecek becerileri sahip olmadan mezun oldukları yönünde bulgular elde edilmiştir. Sonuç olarak programın öğrencilere yeteri kadar deneyimleme firsatı sunamadığı söylenebilir. Dolayısıyla programın, deneyimsel öğrenme alanlarına 
yönelik bütüncül bir yaklaşımla bazı önlemler alması ve buna göre programı geliştirmesi gerektiği söylenebilir.

Sonuçta, araştırma bulguları genel olarak değerlendirildiğinde, programın incelemeye alınan yedi araştırma sorusu bakımından bazı yeterliklere sahip olsa da genel olarak yetersiz kaldığı anlaşılmıştır. Cantor (1995: 4-12) deneyimsel öğrenmenin yükseköğretim kurumlarındaki durumunu analiz ettiği kitabında, programların ögrenme hedeflerine varılabilmesi için öğrenme teorileri ve bilişsel gelişim hakkında artan bir anlayış gösterilmesini, çok sayıda öğrenme stili ve gereksinimi olan öğrenenlerin tanınmasını, yükseköğretimin iş dünyası ve toplumla daha yakın ilişki içinde olması gerektiğini bildirmektedir. Sonuç olarak değerlendirmeye alınan Spor Yöneticiliği lisans programının; sektör iş birliği, sınıfiçi ve dıșı öğrenme etkinlikleri, fiziki çevre, rehberlik hizmetleri, staj eğitimi ve deneyimsel öğrenme çıktıları değişkenlerinin birlikte planlanması tavsiye edilebilir. Ayrıca; programın, deneyimsel öğrenme yaklaşımı kapsamında yeterliğinin nicel araştırma yöntemleriyle de incelenmesi araştırmacılara önerilmektedir.

\section{Teşekkür}

Bu çalışma, Ondokuz Mayıs Üniversitesi BAP birimi (PYO.YDS.1904.18.011) tarafından desteklenmiştir. Ondokuz Mayıs Üniversitesi BAP birimine teşekkür ederiz.

\section{Kaynakça}

Ammar, S. \& Wright, R. (1999). Experiential learning activities in Operations Management. PERGAMON, 6, 183-197.

Ardahan, F. (2010). Sektör odaklı eğitim anlayışıyla Akdeniz Üniversitesi Spor Yöneticiliği Bölümünde okuyan ve mezun öğrencilerinin bölüm tercihi ve aldıkları eğitim ile ilgili düşüncelerinin değerlendirilmesi, Uluslararası Insan Bilimleri Dergisi, 7(2), 696-716. https://doi.org/10.23863/kalem.2019.117

Spor Bilimleri Derneği, (2020, Nisan, 05). Spor Bilimleri Lisans Programları Değerlendirme Ölçütleri. http://sporbilimleri.org.tr/uploads/1575278209df2cd81915982206.pdf

Bennett, G., Henson, R. K. \& Drane, D. (2003). Student experiences with service-learning in sport management. Journal of Experiential Education, 26(2), 61-69. https://doi.org/10.1177/105382590302600203

Brady, L., Mahoney, T.Q., Lovich, J.M. \& Scialabba, M. (2018). Practice makes perfect: Practical experiential learning in sport management. Journal of Physical Education, Recreation \& Dance, 89(9), 32-38. https://doi.org/10.1080/07303084.2018.1512911

Braunstein-Minkove, J.R. \& Deluca, J.R. (2015). Effectively adapting the sport management curricula, SCHOLE: A Journal of Leisure Studies and Recreation Education, 30(2), 12-30. https://doi.org/10.18666/schole-2015-v30-i2-6634

Brickner, D. R. \& Etter, E. R. (2008). Strategies for promoting active learning in a principles of accounting course. Academy of Educational Leadership Journal, 12(2), 87-93.

Cantor, J.A. (1995). Experiential Learning in Higher Education-Linking Classroom, Commonity. ASHE-ERIC Higher Education Report 7.

Casper, M. \& Pfahl, E.M. (2015). Teaching sport management and natural environment. Routledge

Colles, W. \& Alderman, H. (2020). Networks and academic partnerships in international sport management. Goslin, A. (Eds.), Kluka, D. A. (Ed.), López de D'Amico, R. (Eds.) and 
Danylchuk, K. (Eds.). (2020). Managing Sport Across Borders (pp. 222-240). Routledge. https://doi.org/10.4324/9780429316036-11

Cooper, S., Bottomley, C. \& Gordon, J. (2004). Stepping out of the classroom and up the ladder of learning: an experiential learning approach to entrepreneurship education. Industry and Higher Education, 18, 11-22. https://doi.org/10.5367/000000004773040924

Creswell, J.W. (2013). Nitel, nicel ve karma yöntem yaklaşımlarl-Araştırma deseni. Eğiten Kitap.

Cuneen, J. \& Parks, J. (1997). Should we serve sport management practice or sport management education? A response to Weese's perspective. Journal of Sport Management, 11, 125-132. https://doi.org/10.1123/jsm.11.2.125

Cunningham, G.B. Sagas, M., Dixon, M., Kent, A. \& Turner, B.A. (2005). Anticipated career satisfaction, affective occupational commitment, and intentions to enter the sport management profession'. Journal of Sport Management, 19, 43-57. https://doi.org/10.1123/jsm.19.1.43

Çoknaz, D. \& Bulut, D. (2013). Spor Yönetiminde Alan Uygulaması Algılar Beklentiler ve Sorunlar. SSTB Uluslararası Hakemli Akademik Spor Sağglı ve Tip Bilimleri Dergisi, 8(3), 55-67. https://doi.org/10.22396/sbd.2017.18

Dees, W. \& Hall, T. (2012). Creating experiential learning opportunities for sport management students: The case of Gr, Slam Marketing. Sport Management Education Journal, 6, 71-80. https://doi.org/10.1123/smej.6.1.71

Desensi, J. T. \& Kelley, D. R., Blanton, M., Beitel, P. A. (1990). Sport management curricular evaluation and needs assessment: A multifaceted approach. Journal of Sport Management, 4(1), 31-58. https://doi.org/10.1123/jsm.4.1.31

Devecioğlu, S. (2005). Türkiye'de spor sektörü stratejilerinin geliştirilmesi. Verimlilik Dergisi, (2), $1-18$.

Devecioğlu, S., Çoban, B. \& Karakaya, Y. E. (2011). Spor kulüplerinin yönetim modellerinin değerlendirilmesi. Dumlupınar Üniversitesi, Sosyal Bilimler Dergisi, 31, 51-68.

Diacin, M. J. (2018). An experiential learning opportunity for sport management students: Manager interview and facility inspection. Sport Management Education Journal, 12(2), 114-116. https://doi.org/10.1123/smej.2017-0033

Diconti, V.D. (2004). Experiential education in a knowledge based economy: Is it time to reexamine the liberal arts. Journal of General Education, (53), 167-183. https://doi.org/10.1353/jge.2005.0003

Doğan, N. (2003). Pragmatizmin felsefi temelleri. Erciyes Üniversitesi İktisadi ve İdari Bilimler Fakültesi Dergisi, 20, 83-93.

Efstratia, D. (2014). Experiential education through project-based learning. Procedia-social and behavioral sciences, 152, 1256-1260. https://doi.org/10.1016/j.sbspro.2014.09.362

Eratl1-Şirin, Y. \& Şahin, M. (2020). Investigation of factors affecting the achievement of university students with logistic regression analysis school of physical education and sport example. SAGE Open, 10(1), 1-9. https://doi.org/10.1177/2158244020902082

Eyler, J. (2009). The power of experiential education. Liberal Education, 95(4), 24-31.

Fathizadeh, P.E. (2017, April, 19). Experiential Learning through Industry Partnership. https://www.asee.org/public/conferences/78/papers/18679/download 
Faust, J. L. \& Paulson, D. R. (1998). Active learning in the college classroom. Journal on Excellence in College Teaching, 9(2), 3-24.

Ferkins, L. (2002). Sporting best practice: an industry view of work placements. AsiaPacific Journal of Cooperative Education, 3(2), 29-34.

Foster, S.B. \& Dollar, J.E. (2010). Experiential learning in sport management: Internships and beyond. Sheridan Books.

Garrett, P.B. (2013, April, 20). The evolving classroom: creating experiential learning spaces. https://er.educause.edu/articles/2014/10/the-evolving-classroom-creating-experientiallearning-spaces

Gündoğdu, F. \& Sunay, H. (2006). Spor yöneticisinde olması gereken nitelikler üzerine bir araştırma. Gazi Beden Ë̆itimi ve Spor Bilimleri Dergisi, 11(2), 53-68. https://doi.org/10.1501/sporm_0000000082

Güney, A. \& Al-Şensoy, S. (2012). Effective learning environments in relation to different learning theories. Social and Behavioral Sciences. 46, 2334-2338. https://doi.org/10.1016/j.sbspro.2012.05.480

Hardin, R. \& Bemiller, J., Pate, J. (2013). Development and organization of a student-operated sport management cocurricular club: Partners in sports. Sport Management Education Journal, 7(1), 43-50. https://doi.org/10.1123/smej.7.1.43

Healey, M. \& Jenkins, A. (2000). Kolb's experiential learning theory and 1ts application in geography in higher education. Journal of Geography, 99(5), 185195. https://doi.org/10.1080/00221340008978967

Işık, E. \& Semerci, Ç. (2019). Nitel araştırmalarda veri üçgenlemesi olarak odak grup görüşmesi, bireysel görüşme ve gözlem. Turkish Journal of Educational Studies, 6(3), 53-66.

Itin, C. M. (1999). Reasserting the philosophy of experiential education as a vehicle for change in the 21st century. The Journal of Physical Education 22(2), 91-98. https://doi.org/10.1177/105382599902200206

Johnson, D. (1995). Faculty guide to service-learning. Partners in action \& leaming. Dade Community College.

Jones, D.F. Brooks, D.D. \& Mark, J.Y. (2008). Examining sport management programs in the united States. Sport Management Review, 11(1), 77-91. https://doi.org/10.1016/s14413523(08)70104-9

Jowdy, E., Mcdonald, M. \& Spence, K. (2004). An integral approach to sport management internships, European Sport Management Quarterly, 4(4), 215-233. https://doi.org/10.1080/16184740408737478

Judge, L.W., Pierce, D., Petersen, J., Bellar, D., Wanless, E., Gilreath, E. \& Simon, L. (2011). Engaging experiential service learning through a co-curricular club: The Chase Charlie Races. Journal of Research, 6(2), 30-38.

Kandaz-Gelen, N. (2015). Spor yöneticiliği eğitim programının CIPP değerlendirme modeli ve Spor Yönetimi Akreditasyon Komisyonu standartlarına göre yeterliliği [Yayımlanmamıș Doktora Tezi]. Bolu Abant İzzet Baysal Üniversitesi. https://doi.org/10.11616/basbed.vi.455863

Kolb, D.A. (1984). Experiential learning: experiencies as the source of learning and development. Prentice-Hall.

Kolb, D.A. (1999). The Kolb learning style inventory. Hay Resources Direct. 
Kolb, D.A. (2015). Experiential learning experience as the source of learning and development. Upper Saddle River.

Lewis, L.H. \& Williams, C.J. (1994). Experiential learning: Past and present. In L. J. Caffarella (Eds.), Jossey-Bass. Experiential learning (pp. 5-16). Jossey-Bass.

Lidón, I., Rebollar, R. \& Møller, C. (2011). A collaborative learning environment for management education based on experiential learning, Innovations in Education and Teaching International, 48(3), 301-312. https://doi.org/10.1080/14703297.2011.593706

Lumpkin, A. \& Achen, R. M. (2015). Flipping a class: Active learning and more of it. Sport Management Education Journal, 9(2), 79-90. https://doi.org/10.1123/smej.2014-0042

Mcglinn, J. M. (2003). The impact of experiential learning on student teachers. Clearing House. (76), 143-147.

Mcgowan, V. F. (2017). An assessment of service learning objectives and outcomes. Journal of Transformative Learning, (2)4, 43-55.

Melia, A. Krishnan, S. \& Melia, V. (2020, May, 21). Designing experiential learning for student success. http://mams.rmit.edu.au/awzd4ymtl0ht.pdf

Miles, M. B. \& Huberman, A. M. (1994). An expanded sourcebook qualitative data analysis. Thous, Oaks. Sage Publications.

O'shea, M. \& Watson, G. (2007). Academic learning for sport management students: Learning through engaged practise. Asia Pasific Journal of Cooperative Education, 8(1), 53-65.

Ondokuz Mayıs Üniversitesi, (2020, Mayıs 10). Yaşar Doğu Spor Bilimleri Fakültesi. http://ebs.omu.edu.tr/2767/932001

Orejan, M. (2018, April, 22). The value of experiential learning in sport management. Sport Entertainment \& Venues Tomorrow Conference, Columbia, SC. http://sevt.org/abstracts/SEVT-2018F-001.pdf

Parent, M.M. \& Harvey, J. (2009). Towards a management model for sport, physical activity community-based partnerships. European Sport Management Quarterly, 9(1), 23-45. https://doi.org/10.1080/16184740802461694

Pauline, G. \& Pauline, J.S. (2008). Teaching sport sponsorship activation through a client-based experiential learning project. Sport Management Education Journal, 2(1), 19-37. https://doi.org/10.1123/smej.2.1.19

Pierson, M. \& Troppe, M. (2010). Curriculum to career. Peer Review, 12(4), 12.

Ross, C. M. \& Beggs, B. A. (2007). Campus recreational sports internships: A comparison of student and employer perspectives. Recreational Sports Journal, 31, 3-13. https://doi.org/10.1123/rsj.31.1.3

Ross, S. R. \& McCullough, B. P. (2014). Developing a professional perspective. In P. M. Pedersen \& L. Thibault (Eds.), Contemporary sport management (pp. 94-128). Human Kinetics.

Sattler, E.A, (2016). Examining the application of experiential learning techniques across sport management programs [Unpublished Doctoral Thesis]. Illinois State University. https://doi.org/10.30707/etd2016.sattler.e

Schneider, R. C. \& Stier, W. F. (2006). Sport management field experiences as experiential learning: Ensuring beneficial outcomes and preventing exploitation. Sport Management \& Related Topics Journal, 2(2), 40-43. 
Skinner, J. \& Gilbert, K. (2007). Sport management education: teaching and learning for the future. Sport Management Review, 10(2), 125-131. https://doi.org/10.1016/s1441-3523(07)700074

Southall, R. M., Nagel, M. S., Legrande, D. \& Han, P. (2003). Sport management practica: A metadiscrete experiential learning model. Sport Marketing Quarterly, 12(1), 27-36.

Sports Management Accreditation Commission, (2018, November, 01). COSMA Accreditation Principles and Self-Study Preparation. https://www.cosmaweb.org/accreditationmanuals.html

Stoldt, G.C., Dittmore, S.W. \& Pedersen, P.M. (2014). Communication in the sport industry. In P. M. Pedersen \& L. Thibault (Eds.), Contemporary sport management (pp. 338-359). Human Kinetics.

Straughan, P. T., Tay, W. Y. Z. W., Song, E. K. E. \& Koh, L. B. A. (2018). Assessing student learning in sport event management through reflective practice: Measure of success in co-curricular learning in higher education. Research Collection School of Social Sciences, 7, 123-142.

Sunay, H. (1998). Spor yöneticilerinin nitelikleri ve eğitimi. Beden Eğitimi ve Spor Bilimleri Dergisi, (1), 59-68. https://doi.org/10.1501/sporm_0000000182

Sunay, H. (2018). Türkiye ile Amerika Birleşik Devletleri ve Kanada'daki bazı üniversitelerde uygulanan spor yöneticiliği lisans eğitim programlarının karşılaştırmalı incelenmesi. Spormetre, 16(3), 166-186.

Tonbul, Y. (2003). Yükseköğretim kurumlarında aktif öğrenmeyi uygulamada gerekli örgütsel yap1. Ege Eğitim Dergisi, 3(1), 83-95.

West, E. J. (2010). Differences in learning styles and satisfaction between traditional face-to-face and online web-based sport management studies students [Unpublished graduadte dissertation]. East Virginia University, https://doi.org/10.33915/etd.2960

Williams, J. \& Parker, H.M. (2016). Integration of experiential learning and leadership development in a sport management classroom. Sport Management Education Journal, 10, 54-63. https://doi.org/10.1123/smej.2015-0012

Yalçıntaş, M. (2014). Üniversite sanayi devlet iş birliğinin ülke ekonomilerine etkileri: Teknopark İstanbul örneği. Marmara Üniversitesi Finansal Araștırmalar ve Çalışmalar Dergisi, 5(10), 83-106.

Yetim, A.A. \& Şenel, Ö. (2001). Türkiye'de spor yöneticisi yetiştirme faaliyetlerinin görünümü. Milli Eğitim Dergisi, 150.

Yıldırım, A., \& Şimşek, H. (2008). Sosyal bilimlerde nitel araştırma yöntemleri. Seçkin Yayıncılık.

Young, M. R., Caudill, E. M. \& Murphy, J. W. (2008). Evaluating experiential learning activities. Journal for Advancement of Marketing Education, 13, 28-40.

Yükseköğretim Kurulu, (2020, Temmuz, 08). İstatistik. https://istatistik.yok.gov.tr/

Zakus, D.H., Malloy, D.C. \& Edwards, A. (2007). Critical and ethical thinking in sport management: Philosophical rationales and examples of methods. Sport Management Review, 10, 133-158. https://doi.org/10.1016/s1441-3523(07)70008-6 